\title{
Sensory characteristics of wholegrain and bran-rich cereal foods - a review
}

\author{
Heiniö, R.-L. ${ }^{1 *}$, Noort, M.W.J. ${ }^{2}$, Katina, K. ${ }^{3}$, Alam, S.A. ${ }^{1}$, Sozer, N. ${ }^{1}$, de Kock, H.L. ${ }^{4}$, Hersleth, M. ${ }^{5}$, \\ Poutanen, $\mathrm{K}^{1,6}$.
}

${ }^{1}$ VTT Technical Research Centre of Finland Ltd, Finland, Biomass and Food Processing, P.O. Box 1000 (Tietotie 2), FI02044 VTT, Finland

${ }^{2}$ TNO Food and Nutrition, Utrechtseweg 48, 3704 HE Zeist, the Netherlands

${ }^{3}$ University of Helsinki, Department of Food and Environmental Sciences, P.O. Box 66 (Agnes Sjöberginkatu 2), Finland

${ }^{4}$ University of Pretoria, Dept of Food Science, Private Bag X20 Hatfield, Pretoria 0028, South Africa

${ }^{5}$ Nofima AS, P.O. Box 210 (Osloveien 1), NO-1431 Ås, Norway

${ }^{6}$ University of Eastern Finland, Public Health and Clinical Nutrition, P.O. Box 1627, FI-70211 uopio, Finland

*Corresponding author Raija-Liisa Heiniö, E-mail raija-liisa.heinio@ vtt.fi, Mobile: +358 40575 6127, Fax: +358 20722 7071

\begin{abstract}
Wholegrain foods are known to be health-beneficial but their sensory characteristics may be a limiting factor for consumption. Many cereals like rye, oats, barley and sorghum are actually used mainly as wholegrain, whereas for wheat the situation is the opposite. This review deals with factors that differentiate the sensory properties of wholegrain and bran-rich foods from those of refined cereal foods. Hitherto established means of modulating sensory quality and thus improving acceptability of wholegrain foods are also presented.
\end{abstract}

\section{Key words}

- Sensory

- Wholegrain

- Bran

- Cereal

- Wheat, rice, corn, rye, oats, barley, sorghum

- Processing 
- Product

- Bread, biscuit, pasta, snacks

- Flavour, taste, odour, texture

- Structure

- Consumer

- Chemical compounds

\section{Highlights}

- Most sensory attributes of wholegrain foods are formed during processing

- Phenolics, peptides, Maillard reaction products and lipids are the major compounds determining the specific flavour of wholegrain foods

- Bran particle size, surface interactions and water binding are key factors in affecting texture formation

- Milling, fractionation, bioprocessing and choice of raw materials are among the tools to improve the sensory characteristics of wholegrain foods

\section{Introduction}

Cereal grains are a major energy source globally. In Europe, wheat is the most commonly used of all grains. While bread and pasta are elementary parts of the daily diet, the consumption of biscuits, breakfast cereals and snacks is increasing. In the past, cereal foods were based on wholegrain flour. In the 1900s', industrialization brought along development of the milling industry, which led to increased production of refined white flour and separation of the outer bran layers of the kernel mainly to be used as animal feed or biofuel. This refining, driven by facilitated processing, food safety and consumer preferences for white flour, was accompanied by a decrease in intake of dietary fibre (DF) and nutrients present in the wholegrain (Slavin, 2000). In the Western world, due to growing prosperity and abundant availability of food, white wheat flour became the standard raw material for the wheat based cereal industry, leading to product and process development of refined wheat products. In addition to improving public health, utilisation of wholegrains for human food would also contribute to food security and sustainable food production. 
Since the 1970s' there has been a growing understanding of the importance of sufficient DF in the human diet. This led to the current wide recognition of the nutritional significance and health benefits of using wholegrain vs. refined grain. Consumption of foods containing wholegrain and especially cereal DF has in numerous epidemiological studies been shown to reduce the risk of chronic diseases (Ye, Chako, Chou, Kugizaki, \& Liu, 2012), and dietary recommendations in different parts of the world urge to eat more of this kind of foods. However, even though the offering of wholegrain foods is increasing, there is a huge gap between recommendations and intake. This can mainly be attributed to the sensory characteristics vs. consumer expectations. Less than $10 \%$ of the US population was reported to consume the recommended three servings per day in 2000 (Cleveland, Moshfegh, Albertson, \& Goldman, 2000). In UK, only 3\% of adult respondents met the US recommendations of 35 servings/ day (Lang and Jebb, 2003), and 27\% of them were consuming no wholegrain at all (Thane, Jones, Stephen, Seal, \& Jebb, 2005).

Identification of factors underlying flavour and texture formation helps to improve the sensory attributes of cereal products containing wholegrain or bran, and thus contributes to healthier and more sustainable diets. This paper reviews progress in this area, as well as processing techniques which can be utilised to enhance the sensory characteristics and acceptability of wholegrain cereal products.

\section{Consumer perception of wholesome cereal products}

Foods with health benefits need to have high sensory acceptance in order to be chosen and eaten, and it is of great importance to identify causes of sensory concerns in wholegrain foods. In addition to sensory product properties, extrinsic properties such as packaging, product information, claims etc. influence the acceptance of a product. Preferences for the sensory attributes found in refined bread are often stated as the reason for the relatively low consumption of whole wheat bread and other wholegrain cereal foods. Hersleth, Berggren, Westad, and Martens (2005) showed that texture attributes in bread are important for consumers' sensory perception, and Heenan, Dufour, Hamid, Harvey, and Delahunty (2008) demonstrated that odour and flavour attributes are positive drivers of bread freshness. Bakke and Vickers (2007) conducted an acceptance test including nine different breads chosen to represent comparisons between equivalent refined and whole wheat breads, and concluded that sensory preferences may be a barrier to whole wheat bread consumption, but ingredient 
or processing modifications can improve liking of such products. Arvola et al. (2007) suggested that making more wholegrain foods available with sensory characteristics comparable to refined grain foods would be a good strategy to promote wholegrain food consumption. Moreover, traditional bread consumption is changing among young consumers from home use towards fast food bread and bread consumed outside home (Sandvik, Kihlberg, Lindroos, Marklinder, \& Nydahl, 2014). Thus, there is a current need to develop new appealing product concepts as well as tailored communication strategies focused towards younger consumers. Nudging has recently been studied as a tool to influence healthy food choice by affecting unconscious behavioural processes. Van Kleef, Vrijhof, Polet, Vingerhoeds and de Wijk (2014) provided school children with bread in regular or funny shapes. Their intervention study showed that whole wheat bread consumption doubled when presented as fun-shaped products, demonstrating that visual appeal can stimulate wholegrain consumption.

Health information of cereal products induces sensory and hedonic expectations, and it is important that these expectations are fulfilled during consumption (Di Monaco, Cavella, Di Marzo, \& Masi, 2004). Consumers' beliefs and expectations of healthy cereal products have been widely studied lately (Dean et al., 2007; Arvola et al., 2007; Saba et al., 2010; Shepherd et al., 2012), as well as the motivational factors underpinning consumers' understanding of health claims (Dean et al., 2012). Dean et al (2007) showed that nutritional improvements of staple foods were perceived as more beneficial for health than those of fun foods, e.g. pizza, biscuits. Arvola et al (2007) concluded that consumers generally seem to regard cereal products as good for their health. However, the awareness of wholegrain products being healthier for you than refined grain products varied between consumer groups. Country-wise differences in perception of health- related messages in cereal based food products were demonstrated in Saba et al. (2010) and Shepherd et al. (2012).

Schaffer-Lequart et al. (2015) reviewed the current use and challenges of wholegrain in manufactured foods, as well as possibilities to increase the intake. However, their paper did not discuss sensory characteristics of wholegrain products. Consumers' acceptance of wholegrain foods was also recently reported by Kuznesof et al. (2012), who identified that barriers for sufficient intake included taste preferences of the family, cooking skills, price and availability of wholegrain foods. Participants' selfreported benefits of eating wholegrain foods included perceived naturalness, high fibre content, superior taste, improved satiety and increased energy levels. There is clearly a need to take the 
variation between different cultures, traditions and eating habits into account when introducing healthy cereal based products to the market. In any case sensory appeal remains a key food choice factor.

\section{Flavour- active compounds in wholegrains}

Cereal grains each have their characteristic flavour profiles and precursors, even though the flavour of native, untreated grains is mild and bland (Heiniö, 2014). The flavour and texture of cereal foods are mostly formed during processing due to process-induced changes in the grain biopolymers and flavouractive compounds (Figure 1). White wheat flour furnishes a small amount of volatile compounds and

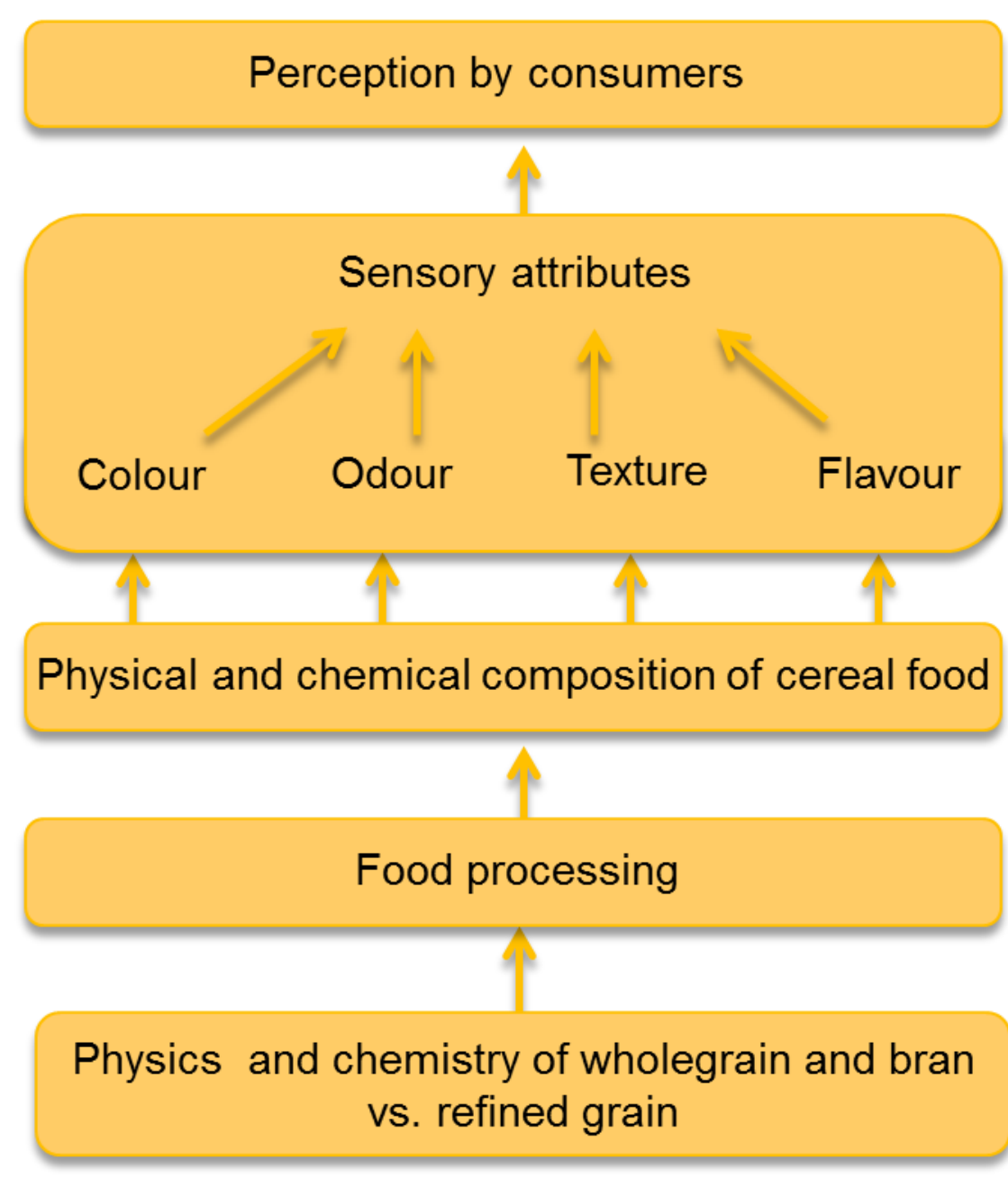

Figure 1. Formation of sensory attributes as interplay of raw materials and processing conditions 
aroma precursors, and their contribution to bread flavour is estimated to be small (Drapron and Molard, 1979). In wholegrain wheat flour, the amount of volatile compounds as well as amino acids is considerably higher (Czerny and Schieberle, 2002). Fermentation and baking are the main sources of flavour of wheat bread, and both steps are essential (Hansen and Schieberle, 2005). Volatile compounds are generated from previous precursors present in ingredients or resulting from enzymatic or mechanical degradations (Drapron and Molard, 1979). The most important precursors of the identified compounds are sugars and amino acids (Spicher and Nierle 1988; Martínez-Anaya, 1996; Thiele, Gänzle, \& Vogel, 2002).

Volatile compounds, such as aldehydes, ketones and alcohols, are perceived as odour, and have traditionally been studied for decades as the only contributors of perceived grain and cereal product flavour causing for example green, sweet and fruity odour notes (Kirchoff \& Schieberle, 2002; Heiniö et al., 2003a). For example, volatile compounds in the headspace of bread give information on the freshness of bread (Heenan, Dufour, Hamid, Harvey, \& Delahunty, 2009). More recently, the role of non-volatile compounds, such as phenolic compounds, amino acids, small peptides, fatty acids and sugars, as flavour- active compounds has been realised (Mattila, Pihlava, \& Hellström, 2005, Heiniö et al., 2008). The most dominant and challenging taste caused by some of these is the bitter note (van Gemert, 2011; Heiniö, 2009; Heiniö, 2014; Heiniö et al., 2008; Heiniö, Nordlund, Poutanen, \& Buchert, 2012). The number of other sensory attributes besides bitterness detected as typical of wholegrain, bran and germ is very limited. Bitter flavour of rice correlates positively with dark colour (Bett-Garber, Lea, Champagne, \& McClung, 2012).

Many bioactive compounds are bitter or astringent in taste, and thus aversive to large consumer groups. Bitterness has even been hypothetized to be linked to likeliness to adopt a healthy diet. Non-volatile chemical compounds are concentrated locally in the grain kernel (Glits $\varnothing$ \& Bach Knudsen, 1999; Heiniö, Liukkonen, Katina, Myllymäki, \& Poutanen, 2003b). Phenolic compounds are located unevenly in the outer layers of grain, making it possible to produce differently flavour-active fractions by milling. For example, different rye fractions - wholegrain, endosperm and differently processed bran fractions - have dissimilar chemical properties and sensory profiles, but also different storage stability (Heiniö, 2003; Heiniö, Liukkonen, Katina, Myllymäki, \& Poutanen, 2003b; Heiniö et al., 2008). Endosperm had the mildest flavour, but its storage stability was poorest. Rye bran, highest in dietary 
fibre and antioxidants, had an intense, bitter flavour, which became more intense during storage with no concurrent increase in rancidity. Between the mild-tasting innermost, endospermic part of rye grain and the bitter-tasting outermost bran fraction, a rye-like flavour without any obvious bitterness was observed. This fraction also contained significant amounts of bioactive compounds, such as alk(en)ylresorcinols and phenolic acids (Heiniö et al., 2008). In sorghum bitterness and astringency are also caused by phenolic compounds, especially by condensed tannins (Kobue-Lekalake, Taylor \& De Kock, 2007; Kobue-Lekalake, 2008).

Bitter and pungent flavour notes are often associated with wholegrain foods. Phenolic compounds are one important contributor of bitterness in cereal products, especially pinoresinol and syringic acid (Heiniö et al., 2008). Only free phenolic compounds are flavour-active because they can adhere to the taste receptors. For example, ferulic acid is the most abundant phenolic acid in rye but is mainly in a bound form and thus not flavour-active. Phenolic compounds often also act as antioxidants in cereal foods, and are thus considered beneficial for health (Fardet, 2010; Bondia-Pons et al., 2009). They are concurrently expected to improve product stability. Phenolic compounds, such as phenolic acids, lignans, alkylresorcinols, benzoxazinoids etc., are mainly located in the outer layers of the grain, and therefore their content is high in products rich in wholegrain and bran (Dimberg, Molteberg, Solheim, \& Frølich, 1996; Heiniö, Liukkonen, Katina, Myllymäki \& Poutanen, 2003b; Heiniö et al., 2008; Andersson, Gimberg, Åman, \& Landberg, 2014). The total phenolic acid content of red and white wholegrain wheat bread and crackers has been shown to correlate with perceived bitterness (Challacombe, Abdel-Aal, Seetharaman, \& Duizer, 2012). Both free and bound phenolic acids correlated with bitterness in bread crumb, whereas only bound phenolic acids did so in crackers. The researchers explained the difference to originate from the different moisture content of the products. However, the reason could also be in different binding of compounds on taste receptors (Soares et al., 2013): the impact of bound phenolic compounds on flavour is expected to be smaller than that of free compounds.

Small molecular weight peptides are considered to be one of the contributors inducing the bitter taste in rye (Heiniö, Nordlund, Poutanen, \& Buchert, 2012). Proteolytic enzymes, mainly located in the outer layers of the kernel, may cause formation of bitter peptides during processing of wholegrain (Brijs, Bleukx, \& Delcour, 1999). Proteolysis of albumins and globulins in wholegrain wheat flour, followed 
by the Maillard reaction, was suggested to be a reason for the bitter notes in wholegrain wheat bread (Jiang \& Peterson, 2013). It was also suggested that the Maillard reaction may be catalysed by presence of phenolics in the wheat grain. Tryptophan and three Maillard reaction products were shown to be mostly responsible for the bitter flavour in wholegrain wheat bread (Bin, Jiang, Cho, \& Peterson, 2012). The amino acid composition of peptides has been considered to be a more important determinant of bitterness than peptide size (Lemieux \& Simard, 1992). Peptides with a molecular mass between 500 and 3000, corresponding to peptides ranging from 2 to 27 amino acids, have been found to be the most bitter ones in dairy (Lee \& Warthesen, 1996a, 1996b) and meat (Henriksen \& Stahnke, 1997) products. The role of peptides and amino acids in perceived flavour of cereal products is, however, largely yet unknown.

Rancidity, as a result of lipid hydrolysis and subsequent fatty acid oxidation, is known to be another contributor to bitterness, and is known to create specific off-flavours. In general, bran and especially germ have higher lipid content than endosperm, and are therefore more susceptible to oxidation. If these lipid-rich parts of grain are used, they obviously contribute a lot to the perceived flavour due to oxidation during storage. The role of lipids depends on the variety of grain: in oats lipids are present in the entire grain, in wheat, corn and sorghum they are concentrated in the germ, and lipid oxidation activity is especially high in barley germ (Baik \& Ullrich, 2008) and pearl millet (Nantanga, Seetharaman, de Kock, \& Taylor, 2008). Among wholegrain foods, the role of lipids has been studied most in oats, which contain about $6 \%$ lipids. Depending on processing conditions, lipid hydrolysis may occur by enzymatic or chemical reactions, and subsequent fatty acid oxidation may create off-flavours. Control of free fatty acid formation is thus important with respect to flavour stability of wholegrain foods.

Lipid hydrolysis has the most significant impact on flavour stability of wholegrain flour, although some smaller changes may also be caused by protein or carbohydrate degradation (Doblado-Maldonado, Pike, Sweley, \& Rose, 2012; Heiniö, Lehtinen, Oksman-Caldentey, \& Poutanen, 2002). During storage, lipolysis takes place, and has a negative impact on the sensory characteristics of flour, perceived as rancid and bitter notes. The shelf-life of whole wheat flour is shorter than that of white flour (Doblado-Maldonado et al 2012). Rancidity appears alike more pronounced in wholegrain than refined wheat bread during storage due to lipid oxidation (Jensen, Oestdal, Skibsted, Larsen, \& Thybo, 
2010; Jensen, Østdal, \& Thybo, 2011). Lipase activity, located mainly in the bran fraction of the grain, causes rancidity by hydrolyzing triacylglycerols to fatty acids (Heiniö et al., 2002). Enzymatic oxidation of free fatty acids is caused by lipoxygenase, located in germ and bran in wheat. Thus, the amount of endogenous lipids in the flour and cereal product greatly influences stability. For example, pearl millet, a very small grain $(3-15 \mathrm{mg}$ ) has a proportionally larger germ than all other cereal grains, except perhaps maize (Nantanga et al., 2008). It tends to contain a proportionally higher content of triglycerides, and is thus extremely susceptible to rancidity within a few days after milling causing offflavours during storage, especially under conditions of moderately high moisture and oxygen exposure. The high phenolic content of bran seems to reduce the formation of flavour-active lipid-derived oxidation products through high antioxidant activity. In the storage of rye grain fractions, triacylglycerols were shown to cause bitterness, whereas free fatty acids caused rancid perception (Nordlund et al., 2013). Increase in flavour intensity and bitterness in bran is due to reactions related either to lipid, protein or phenolic compounds (Table 3).

Oats is different from other cereal grains due to its high $\beta$-glucan and lipid contents and low starch content. Oats has a positive health image, and it is often used as wholegrain. It is perceived as a tasty cereal giving a nutty flavour, but may have a bitter off-flavour originating from its poor stability, and the tendency to rancidity limits the use of oat (Heiniö, Kaukovirta-Norja, \& Poutanen, 2011). Thus, the inhibition of the lipase activity in oat processing is necessary. High water content and phenolic compounds have been shown to contribute to rancidity and bitterness in oat (Molteberg, Solheim, Dimberg, \& Frølich, 1996).

\section{Flavour and texture formation in processing wholegrains and bran}

Good taste, together with other perceived characteristics, is the most important criterion for food choice, and an essential requirement for products to survive on competitive markets. Sensory characteristics of refined and wholegrain products differ in many aspects (Table 1) (Callejo, 2011; Elia, 2011), and cereal products containing wholegrain or bran face numerous challenges in this respect. As compared to refined products, the main sensory concerns and barriers to overcome in wholegrain and high-fibre foods are flavour, texture and colour. 
Table 1. Examples of typical sensory descriptors of wholegrain and white wheat products.

\begin{tabular}{|c|c|c|c|}
\hline Wholegrain & Product & Examples of typical sensory attributes & References \\
\hline \multirow[t]{2}{*}{$\begin{array}{l}\text { Wholegrain } \\
\text { wheat }\end{array}$} & Bread & $\begin{array}{l}\text { Dark colour, 'speckled' appearance } \\
\text { Coarse, hard texture } \\
\text { Nutty odour } \\
\text { Bitter/ sour taste } \\
\text { Grain-like, 'seedy' flavour, malted note, musty }\end{array}$ & $\begin{array}{l}\text { Callejo, Vargas-Kostiuk, M., and } \\
\text { Rodríguez-Quijano (2015) } \\
\text { Challacombe et al. (2012) } \\
\text { Eckardt et al. (2013) } \\
\text { Heenan et al. (2008) } \\
\text { Jensen et al. (2010) } \\
\text { Katina et al. (2006) }\end{array}$ \\
\hline & Biscuit, cracker & $\begin{array}{l}\text { Astringent } \\
\text { High wheat, toasted and earthy notes }\end{array}$ & Challacombe et al. (2012) \\
\hline \multirow[t]{2}{*}{ White wheat } & Bread & $\begin{array}{l}\text { Light colour } \\
\text { Only slight grain-like flavour or malted note }\end{array}$ & $\begin{array}{l}\text { Callejo et al. (2015) } \\
\text { Challacombe et al. (2012) } \\
\text { Eckardt et al. (2013) } \\
\text { Hayakawa et al. (2010) } \\
\text { Heenan et al. (2008) } \\
\text { Jensen et al. (2010) } \\
\text { Katina et al. (2006) } \\
\text { Lotong et al. (2000) }\end{array}$ \\
\hline & Biscuit, cracker & $\begin{array}{l}\text { Only slight wheat, toasted and earthy notes; } \\
\text { strong dairy note }\end{array}$ & Challacombe et al. (2012) \\
\hline
\end{tabular}

Flavour is a simultaneous perception of taste, odour and chemical stimuli. The nature and relative amount of volatile and non-volatile flavour-active compounds, their availability to the senses as a function of time, and the mechanism of perception determine flavour perception (Heiniö, 2003, 2014). Eating is a dynamic process: the profile of compounds in mouth changes as a function of time, when the structure of the food changes during chewing. Flavour perception depends also on chemical and physical binding of the flavour-active compounds within the starch/protein matrix.

Wholegrain products include the outer layers of the grain, which contain several non-volatile, flavouractive substances. Lignocellulosic layers, large particles and insoluble fibre may also cause a hard and gritty texture in a product (Heiniö, 2009). DF content of cereals varies considerably, being $11.2 \%$ in wholewheat flour, $10.6 \%$ in naked oat, $18.5-23.4 \%$ in hulled oat, 17.7-19.3\% in wholegrain rye, 20$24 \%$ in barley and 0.7-19.2\% in rice (Ktenioudaki \& Gallagher, 2012). High DF content decreases loaf volume, increases hardness of crumb, decreases crispiness, changes colour and causes aftertaste in baked products. The colour of bran is often dark, affecting food acceptance. Non-appetising colour, such as a dark colour of rye (Heiniö, 2009, 2014 ), greyish colour of barley (Baik \& Ullrich, 2008), or 
dark colours of rice (Bett-Garber, Lea, Champagne \& McClung, 2012) and sorghum (Kobue-Lekalake, 2008) are suggested to be caused by polyphenols, and often to be associated with bitter or astringent taste (Bett-Garber et al., 2012). Colour and texture may be even more important than flavour for the acceptance by consumers used to eat refined cereal foods.

Raw materials and ingredients are the key factor for flavour formation, but the choice of processing technique and conditions is equally important (Figure 1). Process steps known to influence the flavour of cereal products include mechanical processing, such as milling, fractionation, peeling and flaking of grain; thermal processing, such as baking, extrusion, puffing and roasting where Maillard reaction takes place; or bioprocessing, such as sourdough fermentation, germination/ malting and enzymatic modification (Heiniö, 2003, 2014). Recently, superfine milling (down to $\mathrm{D}_{50}=4 \mu \mathrm{m}$ ) was shown to decrease bitterness and roughness, and increase sweetness of defatted soybean flour (Muttakin, Kim \& Lee 2015).

Potential chemical reactions occurring in processing include non-enzymatic reactions, oxidation and enzymatic reactions induced by endogenic and/or added enzymes (Table 3). As a result of a hot and dry atmosphere, flavour notes and darker colour will appear due to Maillard compounds formed. Eight compounds, both Maillard- and fermentation-derived compounds, were identified as potential chemical markers to predict bitterness of whole-wheat bread (Bin et al., 2012). Bread crust was the most bitter portion of wholegrain wheat bread, and two mechanisms were suggested for bitterness generation: fermentation and Maillard pathways (Jiang \& Peterson, 2013).

At high temperatures, free amino acids or small peptides together with free sugars are especially important flavour precursors and form volatile flavour-active compounds, such as heterocyclic pyrazines, pyrroles, furans, and sulphur-containing compounds. These compounds are especially abundant in high-temperature, low-moisture extruded oats, and the products are described as roasted or toasted, caramelized and somewhat sweet, or nutty in flavour (Heydanek \& McGorrin, 1986; Parker, Hassell, Mottram, \& Guy, 2000; Klensporf \& Jelén, 2008). In contrast, proteolytic reactions release peptides which are perceived as less appealing. Enzymatic reactions release compounds from the matrix, or hydrolyse or oxidise the compounds, and have in that way impact on flavour formation. 
The ash content of flour, indicating presence of outer grain layers and hence more nutrients and precursors for fermentation, has been reported to be a major factor in determining the intensity of the sensory attributes of sourdough bread (Esteve, Barber, \& Martinez-Anaya, 1994), the bread being most preferred if flour with low or medium levels of ash was used (Rouzaud \& Martínez-Anaya, 1997). Utilisation of wholegrain flour in wheat bread increased intensity of flavour, aftertaste and also pungent flavour of bread. Addition of wheat bran (15\% supplementation level) to wheat bread similarly increased flavour intensity, pungent flavour, aftertaste and coarse mouthfeel in sourdough baking (Coda, Rizzello, Curiel, Poutanen, \& Katina, 2014b). Already 5\% bran addition to wheat flour increased the amount of free amino acids, total phenols, dietary fibre, and phytic acid and antioxidant activities of dough compared to white wheat flour, enhancing potentially bitter and pungent flavour notes (Rizzello, Coda, Mazzacane, Minervini, \& Gobbetti, 2012). In addition, sourdough fermentation still increased the amount of these nutrients in baked breads, and concurrently enhanced the intensities of sensory attributes.

\section{Product-specific sensory challenges}

Perceived characteristics of wholegrain foods depend significantly on both grain and food type. Examples of typical sensory descriptors of wholegrain and white wheat foods are presented in Table 1, and of non-wheat wholegrain products in Table 2. Examples of changes in appearance and structure of different wholegrain foods are shown in Table 4 and discussed more detailed below.

\section{Bread baking}

The use of wholegrain or inclusion of bran fractions is known to affect bread processing as well as final product properties. In comparison with white bread, the inclusion of bran fractions results in darker colour, specific flavour, lower specific volume and denser crumb texture (Pomeranz, Shogren, Finney, \& Bechtel, 1977; Gan, Galliard, Ellis, Angold, \& Vaughan, 1992; Lai, Hoseney, \& Davis, 1989; Della Valle et al., 2014), often regarded as negative effects by consumers. The colour and flavour aspects were already discussed above; the reasons related to altered bread structure are discussed here. 
Table 2. Examples of typical sensory descriptors of non-wheat wholegrain products.

\begin{tabular}{|c|c|c|c|}
\hline Wholegrain & Product & Examples of typical sensory attributes & References \\
\hline Rice & Cooked rice & $\begin{array}{l}\text { Brown rice: Grainy/starchy, cooked cereal and } \\
\text { corn/popcorn/buttery flavour } \\
\text { Black rice: Oily, darkberry, medicinal and } \\
\text { smoky/burnt flavour } \\
\text { Red rice: Beany, animal/wet dog and earthy } \\
\text { flavour } \\
\text { Dark cultivars: Bitter taste and astringent } \\
\text { mouthfeel }\end{array}$ & Bett-Garber et al. (2012) \\
\hline Corn/Maize & $\begin{array}{l}\text { Bread } \\
\text { Tortilla } \\
\text { Polenta }\end{array}$ & $\begin{array}{l}\text { White to yellow colour } \\
\text { Slippery, firm, particles } \\
\text { Cooked potato (starch), cooked chestnut, sweet, } \\
\text { metallic, porridge-like, cooked milk, cooked } \\
\text { vegetable, popcorn, toasted and puffed wheat } \\
\text { notes } \\
\text { Bitter taste }\end{array}$ & $\begin{array}{l}\text { Bredie et al. (1998) } \\
\text { Zeppa et al. (2012) }\end{array}$ \\
\hline Rye & $\begin{array}{l}\text { Bread } \\
\text { Snacks }\end{array}$ & $\begin{array}{l}\text { Dark colour } \\
\text { Coarse texture } \\
\text { Grainy odour } \\
\text { Bitter, sour, germ-like, strong flavour and } \\
\text { aftertaste }\end{array}$ & $\begin{array}{l}\text { Heiniö et al. (2003a) } \\
\text { Heiniö et al. (2003b) } \\
\text { Heiniö et al. (2011) }\end{array}$ \\
\hline Oats & $\begin{array}{l}\text { Flakes/ Porridge } \\
\text { Bread }\end{array}$ & $\begin{array}{l}\text { Light colour } \\
\text { Sticky, thick, adherent to spoon, coarse, slippery } \\
\text { texture } \\
\text { Nutty, toasted, cereal, chemical, paint-like, } \\
\text { creamy flavour } \\
\text { Sweet taste }\end{array}$ & $\begin{array}{l}\text { Heiniö et al. (2001) } \\
\text { Heiniö et al. (2002) } \\
\text { Lapveteläinen and Rannikko } \\
\text { (2000) } \\
\text { Molteberg et al. (1996) } \\
\text { Salmenkallio-Marttila et al. } \\
\text { (2004) }\end{array}$ \\
\hline Barley & $\begin{array}{l}\text { Flakes/ Porridge } \\
\text { Bread }\end{array}$ & $\begin{array}{l}\text { Grey colour } \\
\text { Sticky texture } \\
\text { Bitter, astrigent }\end{array}$ & Holtekjølen et al. (2008) \\
\hline Sorghum & $\begin{array}{l}\text { Porridge } \\
\text { Cooked } \\
\text { wholegrains }\end{array}$ & $\begin{array}{l}\text { Dark colour, specky } \\
\text { Cohesive, stiff, sticky, coarse texture, chewy } \\
\text { Branny aroma } \\
\text { Cereal-like, starchy, painty flavour } \\
\text { Astringent, bitter taste }\end{array}$ & $\begin{array}{l}\text { Kebakile et al. (2008) } \\
\text { Kobue-Lekalake et al. (2007) }\end{array}$ \\
\hline
\end{tabular}


Table 3. Key mechanisms leading to bitterness in wholegrain foods.

\begin{tabular}{|l|l|l|}
\hline Action & Mechanism & References \\
\hline Phenolic compounds & $\begin{array}{l}\text { Release of unbound flavour-active phenolic } \\
\text { compounds, such as certain phenolic acids, lignans, } \\
\text { alk(en)ylresorcinols, etc.(especially pinoresinol and } \\
\text { syringic acid) } \\
\text { Tannins }\end{array}$ & $\begin{array}{l}\text { Challacombe et al. (2012) } \\
\text { Heiniö et al. (2008) } \\
\text { Kobue-Lekalake et al. } \\
\text { (2007) } \\
\text { Soares et al. (2013) }\end{array}$ \\
\hline Proteolysis & $\begin{array}{l}\text { Proteolysis of the albumins and globulins forming } \\
\text { bitter peptides }\end{array}$ & $\begin{array}{l}\text { Brijs et al. (1999) } \\
\text { Heiniö et al. (2012) }\end{array}$ \\
\hline Maillard reaction (in roasting) & $\begin{array}{l}\text { Reaction between free amino acids/ small peptides } \\
\text { with free sugars at high temperatures forming volatile } \\
\text { flavour-active compounds, such as heterocyclic } \\
\text { pyrazines, pyrroles, furans and sulphur-containing } \\
\text { compounds }\end{array}$ & $\begin{array}{l}\text { Jiang and Peterson (2013) } \\
\text { Bin et al. (2012) }\end{array}$ \\
\hline Lipid deterioration & $\begin{array}{l}\text { Release of fatty acids in lipolysis. Hydrolytic } \\
\text { rancidity by hydrolyzing triacylglycerols to fatty } \\
\text { acids and other small lipid compounds by lipase. } \\
\text { Enzymatic oxidation of free fatty acids caused by } \\
\text { lipoxygenase. } \\
\text { Triglycerols cause bitterness, and free fatty acids } \\
\text { rancid perception. }\end{array}$ & $\begin{array}{l}\text { Doblado-Madonado et al. } \\
\text { (2012) } \\
\text { Heiniö et al. (2002) } \\
\text { Jensen et al. (2010, 2011) }\end{array}$ \\
\hline
\end{tabular}

Table 4. Typical structural challenges in wholegrain foods.

\begin{tabular}{|l|l|l|}
\hline Product & $\begin{array}{l}\text { Examples of changes in appearance and structure } \\
\text { of wholegrain foods }\end{array}$ & References \\
\hline Bread & $\begin{array}{l}\text { Reduced volume, dense/hard texture, reduced } \\
\text { cohesiveness/increase crumbliness, darker colour, } \\
\text { branny flavour }\end{array}$ & $\begin{array}{l}\text { Pomeranz et al. (1977) } \\
\text { Lai et al. (1989) } \\
\text { Coda et al. (2014b) }\end{array}$ \\
\hline Biscuit & $\begin{array}{l}\text { Increased spread ratio, thinner biscuits, increased } \\
\text { water absorption, harder texture, darker colour }\end{array}$ & $\begin{array}{l}\text { Stanyon and Costell } \\
\text { (1990) } \\
\text { Sudha et al. (2007) } \\
\text { Sozer et al. (2014) }\end{array}$ \\
\hline Extruded snacks & $\begin{array}{l}\text { Reduced expansion, reduced crispiness, hard/crunchy } \\
\text { texture, darker colour }\end{array}$ & $\begin{array}{l}\text { Robin et al. (2011a, } \\
\text { 2011b) } \\
\text { Alam et al.( 2014) } \\
\text { Sibakov et al. (2015) }\end{array}$ \\
\hline Pasta & $\begin{array}{l}\text { Increased surface roughness, less glossy, dark colour, } \\
\text { more chewy, sticky and harder texture }\end{array}$ & $\begin{array}{l}\text { Chillo et al. (2008) } \\
\text { West et al. (2013a, 2013c) } \\
\text { Sobota et al. (2015) }\end{array}$ \\
\hline
\end{tabular}

There is a strong correlation between quality and quantity of flour endosperm protein and bread making quality. Although wholegrain flour in general has higher protein content than refined flour, the proteins of the outer layers have only small contribution to bread quality. This may be due to the different 
biological role and types of proteins in the outer layers (defense layer bran and reproduction part/ germ), vs. the endosperm protein (storage proteins). Because of that it may be evident that wholegrain flour has a lower bread making quality than refined flour due to the dilution of endosperm protein (Gan et al., 1992).

Secondly, the bran components have high water absorbing capacity. During dough mixing, processing and bread storage, bran thus competes with gluten and starch for the available water, negatively influencing bread texture. Therefore, not only the initial water absorption, but also the level of water binding may be of influence. When bran fractions are well hydrated prior to dough mixing, the negative effects on dough mixing properties as well as on bread making quality is partly overcome (Noort, unpublished results). The role of water distribution on texture and staling is ambiguous.

The coarser crumb structure and reduced gas holding capacity of wholegrain dough is often attributed to interference of the gluten network or the dough foam structure by bran particles. Physical hindrance of the gluten network by the introduction of particles has been postulated by Lai et al. (1989). Courtin and Delcour (2002) explained the negative effects of water unextractable arabinoxylans by large fibre particles that may pierce gas cells. In a series of papers, Wang et al. 2003a; Wang, Oudgenoeg, van Vliet, \& Hamer, 2003b; Wang, van Vliet, \& Hamer, 2004a, 2004b reported a systematic study on the effects of both soluble arabinoxylans (WEAX) and water insoluble solids (WUS) of wheat flour on the formation of the gluten network. They concluded that - in principle - both fractions have the same negative effect on gluten formation: less gluten is formed and the gluten is stiffer and less extensible. They hypothesized that arabinoxylans act by a combination of physical and chemical mechanisms. The physical mechanism was related to water binding and size depletion phenomena; the chemical mechanism was related to the presence of ferulic acid. This ligand of arabinoxylans is not only able to mediate AX-AX cross-linking, but - according to these authors - also AX-protein cross-linking, thus changing the agglomeration properties of gluten. Following this approach Noort, van Haaster, Hemery, Schols, and Hamer, (2010) hypothesized that monomeric ferulic acid may be responsible for the chemical effect, and reducing the particle size may increase the reactive surface and hence the amount of negative interactions. 


\section{Biscuit baking}

Biscuits are mainly made of flour, sugar and fat. Sucrose and water from the glassy continuous matrix where mostly ungelatinized starch granules and underdeveloped gluten are embedded. Adding bran particles changes this system remarkably. As reviewed by Pareyt and Delcour (2008), important quality parameters in biscuit baking include the size, i.e. width and height, and bite, i.e. structure. The degree of spread of biscuit dough, determining biscuit size, is controlled by spread rate and set time. Bran or wholegrain flour, having high water binding capacity, often cause decreased spread and changes in biscuit structure. Addition of 20-30\% wheat bran has been shown to render dry mouthfeel and increase biscuit crumbliness and chewiness as well as dark colour (Stanyon \& Costello, 1990; Sudha, Vetrimani, \& Leelavathi, 2007; Sozer, Cicerelli, Heiniö, \& Poutanen, 2014). Whole grain sorghumsoya and pearl millet-soya composite biscuits have shown to have several similar texture attributes as a whole grain wheat biscuit (hardness, roughness, coarseness) but to be darker, less crisp, less dry and denser with a typical sorghum flavour (Omoba et al., 2015). According to Sudha et al 2007 the sensory quality of biscuits was acceptable after addition of $30 \%$ oat bran or $20 \%$ wheat or barley bran. Particle size reduction of wheat bran (from $450 \mu \mathrm{m}$ to $68 \mu \mathrm{m}$ ) increased the elastic modulus and hardness of biscuits at addition level of $15 \%$ of flour mix (Sozer et al., 2014). Addition of wheat bran decreased the intensity of freshness of odour and flavour of biscuits (Sozer et al., 2014), and made the aftertaste and wheat flavour stronger (Sudha et al., 2007).

\section{Extrusion processing}

Extrusion processing is a high temperature short time process which is used to produce directly or indirectly expanded snacks or breakfast cereals. Expansion during extrusion processing is mainly starch driven, and products are generally rich in starch and mainly consist of refined flour (Sozer \& Poutanen, 2013). Extrusion processing can be utilized to develop snacks or breakfast cereals made from wholegrains and bran; although bran addition levels exceeding $15 \%$ of the flour mix would be challenging as there will be an increase in hardness and density along with a reduction in crispiness (Sozer \& Poutanen, 2013). This has been mainly attributed to the presence of insoluble DF leading to decreased expansion. 
Increasing the wholegrain content from 0 to $40-60 \%$ of recipe did not have a significant impact on structural and textural properties of wheat extrudates (Chassagne-Berces et al., 2011). However, a significant decrease in expansion and a drop in structural and instrumental texture quality were observed when 10-20\% of oat and wheat brans were added in the same recipe. High content of wholegrain and bran used together had a profound negative impact on both structure and texture (Chassagne-Berces et al., 2011). These changes might be attributed to the interference of bran with starch continuity during extrusion processing and the latter die expansion. Robin et al. (Robin, Dubois, Curti, Schuchmann, and Palzer (2011a) and Robin, Dubois, Pineau, Schuchmann, and Palzer (2011b)) added 12.6 or $22.4 \%$ wheat bran in wheat flour extrusion, and suggested the reduced expansion to be due to differences in rheological properties of the starch and bran matrices and their interactions and low compatibility.

There are several studies about extrusion of oat flours and brans, showing that a highly expanded oat based extruded product is difficult to achieve due to high contents of lipids and fibre (Liu, Hsieh, Heymann, \& Huff, 2000; Yao, Jannink, Alavi, \& White, 2006; Yao, White, \& Alavi, 2011). High lipid content of oats results in polymer stick-slip phenomenon which might cause instabilities during extrusion processing. Lipid levels of more than $5 \%$ interfere with expansion and result in inferior texture (Cheftel, 1986). Thus it is beneficial to remove excessive lipids from bran prior to extrusion. Wholegrain oat flour was mixed with corn flour with addition levels of 55:45, 70:30, 85:15, and 100:0 (Liu et al., 2000). Increasing the percentage of oat flour resulted in extrudates with a lower specific length, higher bulk density, lower lightness, higher redness, lower yellowness and higher hardness. Sensory profiling was made by descriptive analysis with 10 trained panellists. Principal Component Analysis showed that decreasing moisture content and increasing screw speed resulted in increased product temperature, which was highly correlated with attributes of a more expanded product such as lightness, crispness, shininess, and an open cell structure. Sensory properties such as roughness, compactness, dry surface, curving, and irregular shape increased by increasing the wholegrain oat flour content. The effects of using oat flour with high $\beta$-glucan content $(20 \%)$ vs lower $\beta$-glucan content $(12 \%)$ on wheat flour based extruded snacks were evaluated (Yao, Jannink, Alavi, \& White, 2006). The high water binding capacity of $\beta$-glucan restricted water distribution during extrusion especially at the higher level of $\beta$-glucan, which further reduced expansion, increased hardness and brownness, whereas roasted flavour and gumminess of extrudates were same regardless of $\beta$-glucan content. Wholegrain oat 
flour with $\beta$-glucan content of $8.6 \%, 7.6 \%, 5.3 \%$, and $5.9 \%$ was used in extruded breakfast cereals (Yao, White, \& Alavi, 2011). Based on results of both trained sensory panel $(n=11)$ and a consumer test $(n=115)$ the lowest $\beta$-glucan containing sample was least brown and less hard whereas high level of $\beta$-glucan caused harder product structure.

In a recently published paper defatted wholegrain oat flour (WF) and defatted endosperm oat flour (EF) were extruded with differently treated oat bran fractions [untreated oat bran concentrate (OBC), ultrafine ground, enzymatically hydrolysed and hot water-extracted solubles and insoluble residue] with addition levels of 10 or $20 \%$ (Sibakov et al., 2015). Extrudates made of WF had poor expansion and hard texture compared to EF. Addition of OBC decreased expansion and resulted in a harder texture compared to that of EF $100 \%$ extrudates. The lower expansion of wholegrain and bran enriched extrudates was due to the higher content of insoluble fibre. Water insoluble-OBC fraction significantly decreased expansion and increased hardness, whereas the addition of water soluble-OBC enhanced expansion and resulted in less hard textures (Sibakov et al., 2015). These findings were in line with previous literature showing that soluble fibre promotes expansion and insoluble fibre particles and lipids restrict expansion (Lobato, Anibal, Lazaretti, \& Grossmann, 2011; Parada, Aguilera, \& Brennan, 2011; Yao et al., 2011).

In addition to textural features, the flavour of extrudates is crucial for their acceptability. Although the acceptability and texture of extruded non-tannin sorghum breakfast cereal (up to $70 \%$ sorghum from dry mix) was comparable to the oat reference, the appearance and aroma liking was found to be considerably reduced (Mkandawire et al., 2015). Various pre-treatments used before the extrusion process - sourdough fermentation, germination and milling fractionation -have much larger impact on

adjusting the flavour formation of rye extrudates than the cultivar or extrusion process itself (Heiniö et al., 2003b).

\section{Pasta processing}

Pasta is mainly produced from durum wheat semolina or mixtures of semolina and granular durum wheat flour. Semolina and water (25-30 kg water $/ 100 \mathrm{~kg}$ semolina) are premixed, cold extruded and dried to moisture content around 12.5\%. Wholegrain pasta, like other wholegrain based cereal products, is an excellent source of fibre, mineral and phytochemicals. The total DF content of whole 
grain pasta is between 11.3-13.2\% (Mariani-Costantini, 1988). However, wholegrain or bran enriched pasta is generally not preferred by consumers due to inferior texture, flavour and colour (Edwards, Biliaderis, \& Dexter, 1995; Kordonowy and Youngs, 1985; Sahlstrom, Mosleth, Bævre, Gloria, \& Fayard, 1993; Sozer, Dalg1c, \& Kaya, 2007). Particularly, high hardness and surface stickiness (due to extensive starch leaching) accompanied with high cooking losses in these pasta products are undesirable (Sozer et al., 2007; Sozer, Kaya, \& Dalgic, 2008). These properties are generally associated with the disruption of the continuity of the gluten matrix during dough formation by insoluble fibre particles (Sobota, Rzedzicki, Zarzycki, \& Kuzawińska, 2015).

More than $15 \%$ durum wheat bran and buckwheat addition to wheat semolina gave darker and inferior textural properties compared to durum wheat semolina pasta (Chillo, Lavers, Falcone, Protopapa, \& Del Nobile, 2008). Whole grain pasta had more bitter and branny flavour and more rough texture than pasta made from refined flour (West, Seetharaman, \& Duizer, 2013c). Descriptive analysis on wholegrain and refined flour pastas subjected to low and high temperature drying profile was performed by 12 trained panellists (West, Duizer, \& Seetharaman, 2013a). Wholegrain pasta had significantly lower firmness and higher adhesiveness than the refined flour pasta which was attributed to weak protein network. The values were elevated for low temperature drying profile which was suggested to result in poor starch encapsulation (West et al., 2013a). A trained sensory panel of 12 subjects evaluated wholegrain pasta for flavour interactions with sodium reduced cheese sauce (West, Seetharaman, \& Duizer, 2013b). Wholegrain addition levels were 0\%, 25\%, 75\% and100 \%. Increasing the wholegrain content increased bran flavour, wheat flavour and bitterness but decreased starch flavour and sweetness were noticed. The use of low-sodium cheese sauce in general decreased the flavour intensity for $75 \%$ and $100 \%$ wholegrain pasta but increased the intensity of flavour and bitterness for $0 \%$ and $25 \%$ wholegrain pasta (West et al., 2013c).

Wheat bran enriched durum wheat semolina pasta $(20 \%, 25 \%, 35 \%$ or $40 \%$ bran addition levels to semolina) was compared with commercial wholegrain pasta for appearance, colour, taste, hardness, adhesiveness, chewiness and springiness with a trained sensory panel of 5 subjects (Sobota et al., 2015). The highest colour and appearance scores were obtained for commercial wholegrain pasta whereas increasing the supplementation level of wheat bran in durum wheat semolina resulted in dark, less uniform and less glossy appearance. Beyond 20\% wheat bran addition textural attributes were inferior, i.e. higher hardness, chewiness and adhesiveness but less springiness (Sobota et al., 2015). 
Pasta made with $10 \%$ addition of oat bran and resistant starch was compared to control pasta made with bread flour by a trained sensory panel of 9 experts (Bustos, Perez, \& León, 2011). Pasta with oat bran had the lowest scores for firmness, chewiness, elasticity and highest score for surface stickiness. In order to deliver the positive health effects of oat bran in a palatable pasta formulation it was suggested to use lower supplementation levels (i.e. 5\% of flour) (Bustos et al., 2011). Durum wheat semolina substituted with $0-60 \%$ wheat germ $(5-16.9 \%$ TDF) and $0-30 \%$ wheat bran $(5-14.2 \%$ TDF) was evaluated for appearance, aroma, aftertaste and texture (Aravind, Sissons, \& Fellows, 2012). Pasta with $10 \%$ wheat germ had sensory properties similar to control durum wheat semolina pasta. An unacceptable flavour and texture resulted beyond 30\% wheat germ and $20 \%$ bran addition (Aravind et al., 2012). Bran pasta had significantly darker colour, more surface roughness and hardness than wheat germ added pasta. Wholegrain pasta had more bitter and branny flavour and more rough texture than pasta made from refined flour (West et al 2013c).

\section{$\underline{\text { Porridges }}$}

Porridges or cereal gruels from maize (or corn as is the preferred term in some countries), sorghum (Kebakile, Rooney, de Kock, \& Taylor, 2008) and the millets (Mouquet-Rivier et al., 2008; Nantanga et al., 2008) are staple foods in many African countries. Similar products are also part of the diet in some parts of India. In Western countries, oatmeal porridge is widely used. Dalton, Probst, Batterham, and Tapsell (2014) reported that the wholegrain content of hot porridge type cereals on the Australian market comprised on average $74.5 \pm 8.8 \%$ with a range of $60-96 \%$. The basic porridge making processes for the various cereals are fairly similar but vary depending on the type of product (from stiff to thin and highly viscous). The basic process involves boiling of the meal with water. In some cases the cooking of the porridge is combined with lactic acid fermentation.

The effect of maize cultivar on the descriptive sensory properties of a porridge-type maize dish polenta was published by (Zeppa, Bertolino, \& Rolle, 2012). Thirteen terms (four for odour, three for taste, four for flavour and two for texture) differentiated sensory qualities among polenta samples. Polenta varied in firmness and intensity of cooked corn flavour/aroma. In addition intensity of potato (starch) aroma, presence of particles and bitter versus sweet tastes were also important distinguishing properties. Commercial maize meals are roller-milled to various extraction rates. For example, in South Africa: 'super' maize meal is highly refined and the most expensive but most preferred, 'special' or 
medium refined, and 'sifted' is the least refined and least expensive. In rural areas in Africa many consumers still grow maize on a small scale, to be milled at nearby village-based hammer mills (Khumalo, Schönfeldt, \& Vermeulen, 2011). Consumer perceptions of the sensory attributes of maize meal porridge - aroma, colour, visual consistency, hand feel, grittiness in the mouth and taste - play a major role in overall acceptability. Generally, the whiter and finer the product, the more it is liked. Consumers reported (Khumalo et al., 2011) that they preferred porridge from white polished grains because they cooked more quickly and their taste and texture were 'more desirable than the darker ones'. The wholegrain hammer milled varieties were the ones consumers disliked most because of the coarser texture. While many studies have reported consumer acceptance/preference for particular types of corn/maize porridges (De Groote \& Kimenju, 2012; Khumalo et al., 2011), studies reporting descriptive sensory properties are very limited.

Oats are consumed as a rolled, flaked breakfast cereal throughout the world. Whole oats contain approximately 13\% DF (Soong, Quek, \& Henry, 2015), part of which is soluble $\beta$-glucan. Yao et al., (2011) found that although $\beta$-glucan could increase the adhesiveness of a wet oat food such as porridge, the impact of $\beta$-glucan on the sensory properties of cooked oatmeal was minimal. Lapveteläinen and Rannikko (2000) compared the descriptive sensory properties of cooked oatmeal (rolled oats) from different cultivars. The main sensory appearance and texture differences of oatmeal, due to cultivar, flake thickness and cooking time were; porridge thickness, adherence to spoon, size of swollen flake particles, uniformity of mass, slipperiness, coarseness, and darkness of colour. Odour and flavour were described as fairly weak and terms most often used were toasted, sweet, cereal, and chemical. Zhou, Robards, Glennie-Holmes, and Helliwell (2000) reported that only a few volatiles were detected in oat groats, while more than 50 chromatogram peaks were detected in oatmeals, indicating that most of the volatiles in oatmeals were induced during heat processing. Varietal differences in oat flavour were also detected. The major compounds that related strongly to flavour attributes included hydrocarbons (alkanes: decane, hexadecane, heptadecane, octadecane, nonadecane and eicosane), alcohols (1heptanol, 3-octanol, 2-octanol and 1-octanol), acids (heptanoic acid, octanoic acid, nonanoic acid, dodecanoic acid and palmitic acid) and aldehydes (hexanal, nonanal and decanal).

Kebakile et al. (2008) found that different milling processes had greater effects than sorghum type on sorghum porridge sensory characteristics. Porridges from roller-milled sorghum were generally darker, 
had more specks, tasted more astringent and had more intense bran-like aroma. Porridges from handpounded meals were more stiff and coarse but had rancid off-flavour and humus odour. Porridges obtained from meals prepared using abrasive decortication and hammer milling were lighter in colour, and had more intense cereal aroma and flavour. Sorghums with pigmented pericarps and soft endosperms generally produced dark, specky, and astringent porridges with branny aroma, while lightcoloured hard grains produced light-coloured porridges with more intense cereal flavour and aroma. For high quality sorghum porridge, abrasive decortication and hammer milling were proposed as the best option in addition to using light-coloured hard grain. For consumers in West Africa, the textural characteristics of stickiness in the mouth and cohesiveness were found to be the most important sorghum porridge sensory attributes, followed by the taste and aroma of the product (Aboubacar et al., 1999).

\section{Approaches to improve sensory attributes of wholegrain and bran - containing cereal foods}

The flavour and texture of cereal foods are formed during processing, and the choice of raw materials and ingredients is the first step when considering sensory design (Figure 1). Processing of cereal foods is often made by combination of several unit operations. Technologies used to add more of the grain in cereal foods were recently reviewed by Poutanen, Sozer, \& Della Valle, (2014). In bread baking, for example, means to modulate product quality include selection of the flour type and other ingredients, and improving the gluten network either by using added gluten or dough improvers, or by processing techniques and parameters, such as sourdough fermentation, proofing time and temperatures etc. (Ktenioudaki \& Gallagher, 2012). Use of enzymes is one potential tool for modifying the flavour and especially texture of bakery products. Bioprocessing provides new tools for flavour and texture design of palatable, health-beneficial breakfast and snack applications from cereals by removing unwanted flavours or by enhancing desired flavours. Basic knowledge models will also provide a good basis for design of structure at various levels, provided they also are applied to systems high in bran and wholegrain (Della Valle et al., 2014). 


\section{Breeding or choice of raw materials}

The colour of the pericarp of wheat kernels can vary widely, from white to golden yellow, red and even purple. Most abundant bread making wheats today are red, resulting in distinct red-brown coloured bran particles in wholegrain and overall dark-brown bread. Dark bran usually contains tannins and phenolic acids, which give whole wheat flour the slightly bitter taste, whereas white whole wheat has a mild, sweet and slightly nutty flavour without a trace of bitterness. The use of white wheat varieties is reported to provide products with a lighter colour, but also milder flavour (Doblado-Maldonado, Pike, Sweley, \& Rose, 2012). When the flavour profile of different varieties of wheat was compared, the ancient species Emmer, Einkorn and Spelt as well as some old varieties had milder taste and aroma than the modern varieties in the group tested (Starr, Bredie, \& Hansen, 2013). Comprehensive studies about the genetic variance in flavour profile of grains are not, however, available.

Sorghum cultivars with high levels of condensed tannins have major agronomic advantages, and food products made thereof have a high antioxidant capacity. However, cooked wholegrain kernels from tannin sorghums having a relatively soft endosperm texture were perceived as dark, hard, chewy, bitter and astringent, while tannin-free sorghums having relatively hard endosperm texture were perceived as soft, sweet and having a maize-like flavour (Kobue-Lekalake, Taylor, \& De Kock, 2007). KobueLekalake, Taylor, and De Kock (2009) showed that selection of sorghum cultivars containing low concentration of tannins may both promote health and ensure preference by consumers There seems to be tannin- containing sorghums that are palatable, even to bitter-sensitive consumers, because the tannin levels are below a detection threshold. Such tannin sorghums could be used to produce high antioxidant activity foods that are acceptable to consumers.

\section{Milling and fractionation}

Enzymes, such as peroxidases, polyphenoloxidases and amylases of the aleurone layer are liberated from tissues during milling, leading to off-flavour development, pigment darkening, and starch breakdown. The type of milling technique has been shown to have a greater impact on the sensory quality of wholegrain wheat bread than the baking technique: bread baked with roller-milled wheat was described as being sweet, juicy, and compact, with a small slice area, whereas bread baked with stonemilled wheat was salty, deformed, and roasted (Kihlberg, 2004). Similarly, Kebakile et al. (2008) and Khumalo et al. (2011) showed that different milling methods greatly influenced the sensory properties, 
in particular texture but also visual properties of sorghum and maize porridges. Efficient separation of the pericarp from the starchy endosperm depends on the structural integrity of the pericarp and the milling process used. For sorghum, quantity of specks and porridge colour are associated with pigmentation of testa (if present) and the pericarp properties of the sorghum kernel.

Removal of the very outer layers of the grain in milling (peeling) might offer one tool for improving, in addition to safety, also the texture and flavour of the resulting products (Delcour, Rouau, Courtin, Poutanen, \& Ranieri, 2012). Flavour components are unevenly distributed in the kernel (Heiniö et al., 2003a; Heiniö et al., 2008; Nordlund et al., 2013), and thus choice of suitable milling fractions is one option for production of flours rich in e.g. DF but mild in taste. Between the mild-tasting inner endospermic part of rye grain and the bitter-tasting outermost bran fraction (pericarp), a rather mildtasting fraction (aleurone) was detected still high in bioactive compounds, such as alk(en)ylresorcinols and phenolic acids (Heiniö et al., 2008). Polishing or slight peeling of the grain to remove the surface layers of the grain may also influence processing behaviour by removing microbially derived enzymes and lignocellulosic hard structures covering the grain, while leaving most of the DF and associated compounds in the raw material. Mechanical peeling of rye bran used at $20 \%$ addition level in wheat bread decreased significantly the flavour and colour intensity, but concurrently some of the bioactive compounds located in bran were lost (Heiniö, unpublished results). Fermentation of bran produced from peeled grains improved the flavour of bran-enriched breads.

\section{$\underline{\text { Particle size }}$}

Milling always influences the particle size of flour, and ultrafine milling technologies have recently been exceedingly studied. The particle size of bran influences product quality by changing waterholding, swelling, rheological and fat-binding properties of bran (Chinma, Ramakrishnan, Ilowefah Hanis-Syazwani, \& Muhammad, 2015). The effect of bran particle size on bread making is intensively studied and some contradictory results are reported: For example, Moder, Finney, Bruinsma, Ponte, and Bolte (1984) and Lai et al. (1989) reported positive effects by reducing the particle size, whereas opposite results were reported by Zhang and Moore (1999), De Kock, Taylor, and Taylor (1999), Noort et al. (2010). The contradictions are most probably caused by the use of milling fractions of varying composition, resulting in complex comparisons. In the study of Noort et al (2010), the chemical composition of the bran was kept constant, and a substantial negative effect of particle size reduction 
on bread quality was found, which was demonstrated to be related to decreased gluten aggregation. Crumb colour became darker and more greyish with finer particles, most presumably due to the higher particle surface area of the bran (Coda et al 2014a, Noort, unpublished results).

Particle size reduction may also result in liberation of reactive compounds locked up in the bran matrix or in intact cells as suggested by Noort et al (2010). The outer layers, in particular the aleurone tissue, contain relatively high amounts of compounds which are suspected to influence the baking quality, such as phytic acid, ferulic acid and glutathione. Breakage of intact aleurone cells may release the cell contents and hence liberate these reactive compounds.

On the other hand, for products that do not depend on gluten development, the particle size requirements may be different (Doblado-Maldonado et al., 2012). For extruded snacks, reduction of the particle size may have a positive effect on expansion and texture. This may be explained by the lower water binding capacity of the bran. Particle size reduction of rye bran from $440 \mu \mathrm{m}$ down to $30 \mu \mathrm{m}$ had a significantly positive impact on expansion rate and instrumental crispiness (Alam et al., 2014). Cookie baking quality has also been found to be influenced by wholegrain wheat flour particle size reduction (Charles \& Donelson, 1985). Reduction of the particle size produced more spread (Sozer et al., 2014).

Particle size thus plays an important role in products containing wholegrain and bran. Particle properties are formed in the milling process, the type of which may also be influential, as the shape, porosity and surface properties may be different. It is also obvious that the effects of particle size are different in different processes, particle size reduction being beneficial in expanded snacks and eventually also biscuit baking, whereas in bread baking often not. The absolute particle size distribution may also play a role, and it has been variable in the studies made.

\section{$\underline{\text { Bioprocessing }}$}

Bioprocessing includes use of microbes, enzymes and germination of ingredients at different processing steps. Sourdough fermentation has traditionally been used in processing of wholegrain flour, and is known to influence nutritional and sensory properties as well as stability (Poutanen, Flander, \& Katina, 2009). The reasons for flavour modifications of wholegrain flour are based mainly on: a) 
intensive proteolysis producing amino acids in wholegrain sourdoughs due the activation of cereal proteases at a low $\mathrm{pH}$ during long fermentations, b) release of phenolic compounds from wholegrain flour during fermentation (Liukkonen et al., 2003), and c) more intensive acidification occurring in wholegrain flour as compared to refined flour.

Biochemical changes during fermentation are responsible for both desired and undesired modifications in subsequent bread flavour. Using sourdough as a flavour improver requires therefore carefully optimised fermentation conditions providing moderate acidity and enhanced level of amino acids, as well as enhanced level of certain volatile compounds for producing a balanced bread sensory profile. Furthermore, strain-specific influences on bread flavour are evident (Katina, 2005). In general, lactic acid bacteria (LAB) -containing sourdoughs modify bread flavour more effectively, producing both desired and undesired sensory attributes. Sourdoughs containing yeast modify bread flavour less effectively, and roasted crust flavour cannot be enhanced at all with yeasted sourdoughs. Diminished roasted flavour due to the use of yeasted preferment has been reported by Zehentbauer and Grosch (1998). Yeasted preferment has been reported to either improve (Thiele, Gänzle, \& Vogel, 2002) or have no effect on bread flavour (Lorenz \& Brummer, 2003), opposite results being most likely due to different processing conditions of pre-fermentation and the variation of measured sensory attributes in different studies.

Moderate level of acidity with enhanced levels of amino acids has been obtained by using e.g $L b$. brevis as a starter with wholegrain flour for 20 hours at $24{ }^{\circ} \mathrm{C}$ (Katina et al., 2005), delivering improved flavour. High temperature in combination with long fermentation time is a key factor for intensive acidification in LAB fermented sourdoughs but less important for intensive proteolysis or formation of volatile compounds, or for sensory attributes of subsequent bread. Thus, use of lower temperature allows controlling acidity development and at the same time the high enzyme activity of wholegrain flour and long fermentation time promotes proteolysis.

Fermentation of wholegrain flour or bran in optimized conditions can also improve the volume, texture and shelf-life of wholegrain or fibre-enriched breads (Katina, Heiniö, Autio, \& Poutanen, 2006, Katina et al., 2012, Coda et al., 2014a, 2014b). This has been assumed to be due to partial degradation of bran 
cell walls and solubilization of arabinoxylan, causing improved rheological properties of wheat doughs enriched with wheat bran (Hartikainen, Poutanen, \& Katina, 2014).

Fermentation of bran may also be a useful pre-treatment for extrusion processing. Bioprocessing of rye bran with microorganisms producing exopolysaccharides (EPS) prior to extrusion increased the expansion and crispiness of extruded snacks 10 fold even at $40 \%$ bran addition levels (FI. Patent No. 20145873, 2014). This was probably due to encapsulation of bran particles by EPS which improves the compatibility and interaction of bran with other food matrix components enhancing the expansion which further complements crispiness.

Enzymatic treatment in manufacturing bakery products is an efficient technique for modifying the flavour and texture (Heiniö et al., 2012; Heiniö, 2014). In particular, hydrolytic enzymes have been used for breaking down cell walls or other constituents of the grain. For example, the addition of amylase delays staling of bread by preventing starch retrogradation. Other useful bakery enzymes include xylanase, proteases, lipases and oxidases.

Germination followed by a heat treatment is a well-known process for intensifying both the colour and flavour of grain, and could thus be an optional process for enhancing the sensory characteristics of cereal raw materials. The use of barley malt is common, but germination has been shown to modify the flavour profile also of other grains, such as oats (Heiniö, Oksman-Caldentey, Latva-Kala, Lehtinen, \& Poutanen, 2001; Heiniö et al., 2011). Oat malt has also been shown to be different from wheat and barley malts in tailoring product structure (Mäkinen \& Arendt, 2012).

\section{$\underline{\text { Use of ingredients to mask bitterness of wholegrain }}$}

Bitterness is a common sensory concern of plant derived foods (Table 3) (Drewnowski and GomezCarneros, 2000). Bitter-tasting compounds are therefore often removed from plant foods through breeding or debittering processes. Debittering methods have been suggested for other plant foods, but it is more feasible in liquid food products such as beverages. In wholegrain, the cereal and DF matrices themselves might act as adsorbers of flavour-active compounds, the intensity of which may thus be modulated by processing. Better understanding of taste receptors on the human tongue may lead to 
further innovations in flavour-masking systems. In addition to masking, the perception of bitterness can be reduced by blocking the bitter taste receptor hTAS2R39 (Roland, 2014). Three 6methoxyflavanones were shown to reduce hTAS2R39 activation by epicatechin gallate (ECG). These bitter receptor blockers were characterized as reversible antagonists. Furthermore, complexation of epigallocatechin gallate (EGCG) with food proteins reduced hTAS2R39 activation. A trained sensory panel confirmed reduced bitterness perception.

Sweeteners are often used as flavour-masking agents in whole grain products, and e.g. breakfast cereals made of wheat bran contain over $10 \%$ sugar. Many bakers are turning to honey to build on its ability to mask off-flavours of wholegrain wheat. In addition to sweeteners, also salt may offer an option in masking the bitter taste. The bitterness and astringency of rice have shown to be significantly reduced by adding salt or salt with oil to water in cooking (Bett-Garber, Lea, Watson, \& Champagne, 2013). This could also be the case in mixed meals, like pasta with cheese souce, as sodium cations have been shown to mask bitter compounds (Keast, Breslin, \& Beauchamp, 2001). Masking bitter off-notes in wholegrain products may be complex in terms of understanding the difference between singular and multi-dimensional off-notes which require masking. Three approaches in masking off-notes in wholegrain products have been suggested: a) adding lubricity via saliva-stimulating agents, b) mouthfeel-enhancers and fat-simulators; masking the bitter and oxidized notes often present in whole grain products, particularly by enhancing sweetness, and c) using delivery systems to prevent flavour compounds forming complexes with fibre.

Inferior texture formation properties of wholegrain flour can be compensated by adding standard baking aids such as gluten, emulsifiers, enzymes and by optimisation of the baking process (Flander et al. 2012). A widely used way to reduce the negative effects of bran is by compensations made in the bread formula by addition of vital gluten, or the use of surfactants (Shogren, Pomeranz, \& Finney, 1981). 


\section{Conclusions and future trends}

Wholegrain and bran are among the health beneficial ingredients which consumption should be increased. They contain flavour-active compounds and flavour precursors as well as resistant cell wall structures which may during processing cause changes in flavour and texture attributes reducing their acceptance of wholegrain foods by consumers. Considering the major role of cereal foods in daily diet and nutrition, it is surprising that the scientific literature of factors influencing sensory quality of wholegrain foods is rather limited. It is also interesting that actually many food grains, with the exception of wheat, are traditionally used as wholegrain. The concern about increasing the use of whole vs. refined grain foods has thus been largest in case of wheat products.

Bitterness is the key sensory attribute known to restrict the use of many plant-derived foods. In wholegrain foods, different chemical constituents contribute to bitterness: e.g. certain phenolic compounds, peptides, and Maillard reaction compounds. While their intensities can be controlled by careful choice of raw materials, processing is the most important step to control bitterness. As the flavour stimuli are created in bitter taste receptors, controlling their activation is one key area for future research. Binding of bitter-tasting compounds in the cereal food matrix, e.g. through the use of natural or added adsorbents, is another option. Control of endogenous enzymes in the raw material is also essential, as formation of peptides and oxidation of lipids may add off-flavours to wholegrain foods. Enzymes, both those in grains themselves and added as processing aids, are on the other hand a good tool especially in design of texture but also flavour of wholegrain foods. This is one of the reasons for the traditional sourdough processing in baking of wholegrain breads, a technique also having clear future potential.

The research into flavour formation of refined wheat foods and later also other cereal foods has a long history, but has almost only concentrated on the research of volatile compounds in the headspace of the product. This is a very limited approach for understanding perceived flavour. Increased knowledge on flavour formation has led to the possibility to not only measure but actually also design the flavour. This is a great option to improve the acceptance and increase the use of wholegrain products. 
The dark colour of wholegrain products may not be appealing to consumers currently choosing refined products. By using white wheat varieties or by fractionation processing products with lighter colour, but also milder flavour, can be obtained.

Structure and texture are also important determinants underlying eating quality and stability of cereal foods. Current fine milling techniques have enabled production of ingredients of various particle size. Analysis of structure formation at various scales of the heterogeneous systems consisting of various biopolymers and also insoluble constituents will make the basis for applying modeling techniques to predict product quality attributes. Water binding and rheological properties of dough and bread change remarkably with increased DF content, and demand the extension of the current knowledge models to even more complex systems.

\section{Acknowledgements}

This work was performed as part of the activities of the Healthgrain Forum. Funding from Academy of Finland for Kaisa Poutanen is gratefully acknowledged.

\section{References}

Aboubacar, A., Kirleis, A. \& Oumarou, M. (1999). Important sensory attributes affecting consumer acceptance of sorghum porridge in West Africa as related to quality tests. Journal of Cereal Science, 30(3), 217-225.

Adams, J., \& Engstrom, A. (2000). Dietary intake of whole grain vs. recommendations. Cereal Foods World, 45(2), $75-78$.

Alam, S. A., Järvinen, J., Kirjoranta, S., Jouppila, K., Poutanen, K., \& Sozer, N. (2014). Influence of particle size reduction on structural and mechanical properties of extruded rye bran. Food and Bioprocess Technology, 7(7), 2121-2133. doi: 10.1007/s11947-013-1225-2

Andersson, A. A. M., Gimberg, L., Åman, P., \& Landberg, R. (2014). Recent findings on certain bioactive compounds in whole grain wheat and rye. Journal of Cereal Science, 59, 294-311. doi: 10.1016/j.jcs.2014.01.003

Aravind, N., Sissons, M., \& Fellows, C. M. (2012). Effect of soluble fibre (guar gum and carboxymethylcellulose) addition on technological, sensory and structural properties of durum wheat spaghetti. Food Chemistry, 131(3), 893-900. doi: 10.1016/j.foodchem.2011.09.073

Arvola, A., Lähteenmäki, L., Dean, M., Vassallo, M., Winkelmann, M., Claupein, E., et al. (2007). Consumers' beliefs about whole and refined grain products in the UK, Italy and Finland. Journal of cereal science, 46(3), $197-206$. doi: $10.1016 /$ j.jcs.2007.06.001 
Baik, B., \& Ullrich, S. E. (2008). Barley for food: characteristics, improvement, and renewed interest. Journal of Cereal Science, 48(2), 233-242. doi:10.1016/j.jcs.2008.02.002

Bakke, A., \& Vickers, Z. (2007). Consumer liking of refined and whole wheat breads. Journal of Food Science, 72(7), S473-S480. doi: 10.1111/j.1750-3841.2007.00440.x

Belitz, H., \& Grosch, W. (1999). Food Chemistry (2nd edition). New York: Springer-Verlag Berlin Heidelberg.

Bett-Garber, K. L., Lea, J. M., Watson, M. A., \& Champagne, E. T. (2013). Influence of cooking formulation on flavor and hydrophilic oxygen radical absorption capacity values of whole grain colored rice. Cereal Chemistry, 90(1), 58-64. doi: 10.1094/CCHEM-01-12-0004

Bett-Garber, K., Lea, J., Champagne, E., \& McClung, A. (2012). Whole-grain rice flavor associated with assorted bran colors. Journal of Sensory Studies, 27(2), 78-86. doi: 10.1111/j.1745-459X.2011.00368.x

Bin, Q., Jiang, D., Cho, I. H., \& Peterson, D. G. (2012). Chemical markers for bitterness in wheat bread. Flavour and Fragrance Journal, 27(6), 454-458. doi: 10.1002/ffj.3124

Bondia-Pons, I., Aura, A., Vuorela, S., Kolehmainen, M., Mykkänen, H., \& Poutanen, K. (2009). Rye phenolics in nutrition and health. Journal of cereal science, 49(3), 323-336. doi: 10.1016/j.jcs.2009.01.007

Bredie, W. L. P., Mottram, D. S., Hassell, G. M., \& Guy, R. C. E. (1998). Sensory characterisation of the aromas generated in extruded maize and wheat flour. Journal of cereal science, 28(1), 97-106. doi: $10.1006 /$ jcrs.1997.0172

Brijs, K., Bleukx, W. \& Delcour, J. A. (1999). Proteolytic activities in dormant rye (Secale cereale L.) grain. Journal of Agricultural and Food Chemistry, 47(9), 3572-3578. doi: 10.1021/jf990070t

Bustos, M. C., Perez, G. T., \& León, A. E. (2011). Sensory and nutritional attributes of fibre-enriched pasta. LWTFood Science and Technology, 44(6), 1429-1434.

Callejo, M. J. (2011). Present situation on the descriptive sensory analysis of bread. Journal of Sensory Studies, 26(4), 255-268. doi: 10.1111/j.1745-459X.2011.00341.x

Callejo, M. J., Vargas-Kostiuk, M., \& Rodríguez-Quijano, M. (2015). Selection, training and validation process of a sensory panel for bread analysis: Influence of cultivar on the quality of breads made from common wheat and spelt wheat. Journal of Cereal Science, 61, 55-62. doi: 10.1016/j.jcs.2014.09.008

María Jesús Callejo, María-Eugenia Vargas-Kostiuk, Marta Rodríguez-Quijano (2015). Selection, training and validation process of a sensory panel for bread analysis: Influence of cultivar on the quality of breads made from common wheat and spelt wheat. Journal of Cereal Science 61 (2015) 55-62

Cassone, D. R., Duffin, M. A., Gannon, D. L., Hansen, T. S., Haynes, L. C., Manns, J. M., et al. (2012). WO Patent Application. PCT/US2012/033,500. Method to extend whole grain flour and product shelf life. Location: Source Name.

Challacombe, C. A., Abdel-Aal, E. M., Seetharaman, K., \& Duizer, L. M. (2012). Influence of phenolic acid content on sensory perception of bread and crackers made from red or white wheat. Journal of cereal science, 56(2), 181-188. doi: 10.1016/j.jcs.2012.03.006

Champagne, E. T., Bett, K. L., Vinyard, B. T., Webb, B. D., McClung, A. M., Barton, F. E., et al. (1997). Effects of drying conditions, final moisture content, and degree of milling on rice flavour. Cereal Chemistry, 74(5), 566-570. doi: 10.1094/CCHEM.1997.74.5.566 
Chassagne-Berces, S., Leitner, M., Melado, A., Barreiro, P., Correa, E. C., Blank, I., et al. (2011). Effect of fibers and whole grain content on quality attributes of extruded cereals. Procedia Food Science, 1(0), 17-23. doi: 10.1016/j.profoo.2011.09.004

Cheftel, J. C. (1986). Nutritional effects of extrusion-cooking. Food Chemistry, 20(4), 263-283.

Chinma, C. E., Ramakrishnan, Y., Ilowefah, M, Hanis-Syazwani, M., \& Muhammad, K. (2015). Properties of cereal brans: A review. Cereal Chemistry, 92(1), 1-7. doi: 10.1094/CCHEM-10-13-0221-RW

Chillo, S., Laverse, J., Falcone, P., Protopapa, A., \& Del Nobile, M. (2008). Influence of the addition of buckwheat flour and durum wheat bran on spaghetti quality. Journal of Cereal Science, 47(2), 144-152.

Cleveland, L. E., Moshfegh, A. J., Albertson, A. M., \& Goldman, J. D. (2000). Dietary intake of wholegrains. Journal of the American College of Nutrition, 19(sup3), 331S-338S. doi: 10.1080/07315724.2000.10718969

Coda, R., Kärki, I., Nordlund, E., Heiniö, R., Poutanen, K. \& Katina, K. (2014a). Influence of particle size on bioprocess induced changes on technological functionality of wheat bran. Food Microbiology, 37, 69-77. doi: 10.1016/j.fm.2013.05.011

Coda, R., Rizzello, C. G., Curiel, J. A., Poutanen, K. \& Katina, K. (2014b). Effect of bioprocessing and particle size on the nutritional properties of wheat bran fractions. Innovative Food Science \& Emerging Technologies, 25, 19-27. doi: $10.1016 /$ j.ifset.2013.11.012

Courtin, C., \& Delcour, J. A. (2002). Arabinoxylans and endoxylanases in wheat flour bread-making. Journal of Cereal Science, 35(3), 225-243. doi:10.1006/jcrs.2001.0433

Curti, E., Carini, E., Bonacini, G., Tribuzio, G., \& Vittadini, E. (2013). Effect of the addition of bran fractions on bread properties. Journal of Cereal Science, 57(3), 325-332. doi: 10.1016/j.jcs.2012.12.003

Czerny, M., \& Schieberle, P. (2002). Important aroma compounds in freshly ground wholemeal and white wheat flour Identification and quantitative changes during sourdough fermentation. Journal of Agricultural and Food Chemistry, 50(23), 6835-6840. doi: 10.1021/jf020638p

Dalton, S. M., Probst, Y. C., Batterham, M. J., \& Tapsell, L. C. (2014). Compilation of an Australian database of manufactured and packaged food products containing wholegrain ingredients. Journal of Food Composition and Analysis, 36(1), 24-34. doi: 10.1016/j.jfca.2014.04.012

De Groote, H., \& Kimenju, S. C. (2012). Consumer preferences for maize products in urban Kenya. Food \& Nutrition Bulletin, 33(2), 99-110.

De Kock, S., Taylor, J., \& Taylor, J. R. N. (1999). Effect of heat treatment and particle size of different brans on loaf volume of brown bread. LWT-Food Science and Technology, 32(6), 349-356. doi: 10.1006/fstl.1999.0564

Delcour, J. A., Rouau, X., Courtin, C. M., Poutanen, K. \& Ranieri, R. (2012). Technologies for enhanced exploitation of the health-promoting potential of cereals. Trends in Food Science \& Technology, 25(2), 78-86. doi:10.1016/j.tifs.2012.01.007

Dean, M., Lampila, P., Shepherd, R., Arvola, A., Saba, A., Vassallo, M., et al. (2012). Perceived relevance and foods with health-related claims. Food Quality and Preference, 24(1), 129-135. doi: 10.1016/j.foodqual.2011.10.006

Dean, M., Shepherd, R., Arvola, A., Vassallo, M., Winkelmann, M., Claupein, E., et al. (2007). Consumer perceptions of healthy cereal products and production methods. Journal of cereal science, 46(3), 188-196. doi: 10.1016/j.jcs.2007.06.007 
Della Valle, G., Chiron, H., Cicerelli, L., Kansou, K., Katina, K., Ndiaye, A., Whitworth, M., \& Poutanen, K. (2014). Basic knowledge models for the design of bread texture. Trends in Food Science \& Technology, 36(1), 5-14. doi: 10.1016/j.tifs.2014.01.003

Di Monaco, R., Cavella, S., Di Marzo, S., \& Masi, P. (2004). The effect of expectations generated by brand name on the acceptability of dried semolina pasta. Food Quality and Preference, 15(5), 429-437. doi: 10.1016/j.foodqual.2003.07.003

Dimberg, L., Molteberg, E., Solheim, R., \& Frølich, W. (1996). Variation in oat groats due to variety, storage and heat treatment. I: Phenolic compounds. Journal of cereal science, 24(3), 263-272. doi: 10.1006/jcrs.1996.0058

Doblado-Maldonado, A. F., Pike, O. A., Sweley, J. C., \& Rose, D. J. (2012). Key issues and challenges in whole wheat flour milling and storage. Journal of cereal science, 56(2), 119-126. doi: 10.1016/j.jcs.2012.02.015

Drapron, R., \& Richard-Molard, D. (1979). Influence de divers procédés technologiques sur la formation de l'arôme du pain. Répercussions sur sa qualité. Le Pain, 143-161.

Drewnowski, A., \& Gomez-Carneros, C. (2000). Bitter taste, phytonutrients, and the consumer: a review. The American Journal of Clinical Nutrition, 72(6), 1424-1435.

Eckardt, J., Öhgren, C., Alp, A., Ekman, S., Åström, A., Chen, G., Swenson, J., Johansson, D., \& Langton, M. (2013). Long-term frozen storage of wheat bread and dough-Effect of time, temperature and fibre on sensory quality, microstructure and state of water. Journal of cereal science, 57(1), 125-133. doi: 10.1016/j.jcs.2012.10.007

Edwards, N., Biliaderis, C., \& Dexter, J. (1995). Textural Characteristics of Wholewheat Pasta and Pasta Containing Non-Starch Polysaccharides. Journal of Food Science, 60(6), 1321-1324.

Elia, M. (2011). A procedure for sensory evaluation of bread: protocol developed by a trained panel. Journal of Sensory Studies, 26(4), 269-277. doi: 10.1111/j.1745-459X.2011.00342.x

Engelen, L., van den Keybus, P. A. M., de Wijk, R. A., Veerman, E. C., Amerongen, A. V., Bosman, F., et al. (2007). The effect of saliva composition on texture perception of semi-solids. Archives of Oral Biology, 52(6), 518-525. doi: $10.1016 / j$.archoralbio.2006.11.007

Esteve, C. C., Barber, C. B., \& Martinez-Anaya, M. A. (1994). Microbial sour doughs influence acidification properties and breadmaking potential of wheat dough. Journal of Food Science, 59(3), 629-633. doi: 10.1111/j.1365-2621.1994.tb05579.x

Fardet, A. (2010). New hypotheses for the health-protective mechanisms of whole-grain cereals: what is beyond fibre?. Nutrition Research Reviews, 23(01), 65-134. doi: 10.1017/S0954422410000041

Charles, S. G., \& Donelson, J. R. (1985). Evaluating cookie spread potential of whole wheat flours from soft wheat cultivars. Cereal Chemistry, 62(2), 134-136.

Gan, Z., Galliard, T., Ellis, P., Angold, R., \& Vaughan, J. (1992). Effect of the outer bran layers on the loaf volume of wheat bread. Journal of Cereal Science, 15(2), 151-163. doi: 10.1016/S0733-5210(09)80066-0

Glitsø, L. V., \& Bach Knudsen, K. E. (1999). Milling of whole grain rye to obtain fractions with different dietary fibre characteristics. Journal of cereal science, 29(1), 89-97. doi: 10.1006/jcrs.1998.0214

Haglund, Å., Johansson, L., \& Dahlstedt, L. (1998) Sensory evaluation of wholemeal bread from ecologically and conventionally grown wheat. Journal of cereal science, 27(2), 199-207. doi: 10.1006/jcrs.1997.0155 
Hansen, A., \& Schieberle, P. (2005). Generation of aroma compounds during sourdough fermentation: applied and fundamental aspects. Trends in Food Science \& Technology, 16(1), 85-94. doi: 10.1016/j.tifs.2004.03.007

Hartikainen, K., Poutanen, K., \& Katina, K. (2014). Influence of bioprocessed wheat bran on the physical and chemical properties of dough and on wheat bread texture. Cereal Chemistry, 91(2), 115-123. doi: 10.1094/CCHEM-04-13-0074-R

Hayakawa, F., Ukai, N., Nishida, J., Kazami, Y., \& Kohyama, K. (2010). Lexicon for the sensory description of French bread in Japan. Journal of Sensory Studies, 25(1), 76-93. doi: 10.1111/j.1745-459X.2009.00247.x

Heenan, S. P., Dufour, J., Hamid, N., Harvey, W., \& Delahunty, C. M. (2008). The sensory quality of fresh bread: Descriptive attributes and consumer perceptions. Food Research International, 41(10), 989-997. doi: 10.1016/j.foodres.2008.08.002

Heenan, S. P., Dufour, J., Hamid, N., Harvey, W., \& Delahunty, C. M. (2009). Characterisation of fresh bread flavour: Relationships between sensory characteristics and volatile composition. Food Chemistry, 116(1), 249-257. doi: 10.1016/j.foodchem.2009.02.042

Heiniö, R-L. (2003). Influence of processing on the flavour formation of oat and rye. (Doctoral dissertation). Retrived from VTT Technical Research Centre of Finland Publications Register. (VTT Publications 494). http://www.vtt.fi/inf/pdf/publications/2003/P494.pdf Accessed on 3rd March 2015.

Heiniö, R-L. (2009). Comparison of sensory characteristics of refined and whole grain foods. Cereal Foods World, $54(2), 12-13$.

Heiniö, R-L. (2014). Sensory attributes of bakery products. In W. Zhou, Y. H. Hui, I. De Leyn, M. A. Pagani, C. M. Rosell, J. D. Selman \& N. Therdthai (Eds.), Bakery products science and technology (pp. 391-407). West Sussex, UK: John Wiley \& Sons.

Heiniö, R-L., Oksman-Caldentey, K., Latva-Kala, K., Lehtinen, P., \& Poutanen, K. (2001). Effect of drying treatment conditions on sensory profile of germinated oat. Cereal Chemistry, 78(6), 707-714. doi: 10.1094/CCHEM.2001.78.6.707

Heiniö, R-L., Lehtinen, P., Oksman-Caldentey, K., \& Poutanen, K. (2002). Differences between sensory profiles and development of rancidity during long-term storage of native and processed oat. Cereal Chemistry, 79(3), 367-375. doi: 10.1094/CCHEM.2002.79.3.367

Heiniö, R-L., Katina, K., Wilhelmson, A., Myllymäki, O., Rajamäki, T., Latva-Kala, K., et al. (2003a). Relationship between sensory perception and flavour-active volatile compounds of germinated, sourdough fermented and native rye following the extrusion process. LWT-Food Science and Technology, 36(5), 533-545. doi: $\underline{10.1016 / \mathrm{S} 0023-6438(03) 00057-4}$

Heiniö, R-L., Liukkonen, K., Katina, K., Myllymäki, O., \& Poutanen, K. (2003b). Milling fractionation of rye produces different sensory profiles of both flour and bread. LWT-Food Science and Technology, 36(6), 577-583. doi: $10.1016 / \mathrm{S} 0023-6438(03) 00063-\mathrm{X}$

Heiniö, R-L., Liukkonen, K., Myllymäki, O., Pihlava, J., Adlercreutz, H., Heinonen, S., et al. (2008). Quantities of phenolic compounds and their impacts on the perceived flavour attributes of rye grain. Journal of cereal science, 47(3), 566-575. doi: 10.1016/j.jcs.2007.06.018

Heiniö, R-L., Kaukovirta-Norja, A., \& Poutanen, K. (2011). Flavor in processing new oat foods. Ceral Food Worlds, $56(1), 21-26$.

Heiniö, R-L., Nordlund, E., Poutanen, K., \& Buchert, J. (2012). Use of enzymes to elucidate the factors contributing to bitterness in rye flavour. Food Research International, 45(1), 31-38. doi: 10.1016/j.foodres.2011.10.006 
Henriksen, A. P., \& Stahnke, L. H. (1997). Sensory and chromatographic evaluations of water soluble fractions from dried sausages. Journal of Agricultural and Food Chemistry, 45(7), 2679-2684. doi: 10.1021/jf960792+

Hersleth, M., Berggren, R., Westad, F., \& Martens, M. (2005). Perception of bread: A comparison of consumers and trained assessors. Journal of Food Science, 70(2), 95-101. doi: 10.1111/j.1365-2621.2005.tb07123.x

Heydanek, M. G. \& McGorrin, R. J. (1986). Oat Flavor Chemistry: Principles and Prospects. In F. H. Webster (Ed.). Oats: Chemistry and Technology, (pp 335-369). St. Paul, MN: American Association of Cereal Chemists.

Holtekjølen, A. K., Bævre, A., Rødbotten, M., Berg, H., \& Knutsen, S. H. (2008). Antioxidant properties and sensory profiles of breads containing barley flour.Food Chemistry, 110(2), 414-421.

Jensen, S., Oestdal, H., Skibsted, L. H., Larsen, E., \& Thybo, A. K. (2011). Chemical changes in wheat pan bread during storage and how it affects the sensory perception of aroma, flavour, and taste. Journal of cereal science, 53(2), 259-268. doi: 10.1016/j.jcs.2010.11.007

Jensen, S., Østdal, H., \& Thybo, A. K. (2010). Sensory profiling of changes in wheat and whole wheat bread during a prolonged period of storage. Journal of Sensory Studies, 25(2), 231-245. doi: 10.1111/j.1745459X.2009.00254.x

Jiang, D., \& Peterson, D. G. (2013). Identification of bitter compounds in whole wheat bread. Food Chemistry, 141(2), 1345-1353. doi: 10.1016/j.foodchem.2013.03.021

Katina, K. (2005). Sourdough: a tool for the improved flavour, texture and shelf life of wheat bread. (Doctoral dissertation). Retrived from VTT Technical Research Centre of Finland Publications Register. (VTT Publications 569). http://www.vtt.fi/inf/pdf/publications/2005/P569.pdf Accessed on 3rd March 2015.

Katina, K., Arendt, E., Liukkonen, K., Autio, K., Flander, L., \& Poutanen, K. (2005). Potential of sourdough for healthier cereal products. Trends in Food Science \& Technology, 16(1), 104-112. doi:10.1016/j.tifs.2004.03.008

Katina, K., Heiniö, R-L., Autio, K., \& Poutanen, K. (2006). Optimization of sourdough process for improved sensory profile and texture of wheat bread. LWT-Food Science and Technology, 39(10), 1189-1202. doi: $\underline{10.1016 / j .1 w t .2005 .08 .001}$

Katina, K., Juvonen, R., Laitila, A., Flander, L., Nordlund, E., Kariluoto, S., et al. (2012). Fermented wheat bran as a functional ingredient in baking. Cereal Chemistry 89(2), 126-134. doi: 10.1094/CCHEM-08-11-0106

Katina, K., Salmenkallio-Marttila, M., Partanen, R., Forssell, P., \& Autio, K. (2006). Effects of sourdough and enzymes on staling of high-fibre wheat bread. LWT-Food Science and Technology, 39(5), 479-491. doi: $\underline{10.1016 / j .1 w t .2005 .03 .013}$

Keast, R. S., Breslin, P. A., \& Beauchamp, G. K. (2001). Suppression of bitterness using sodium salts. Chimia International Journal for Chemistry, 55(5), 441-447.

Kebakile, M. M., Rooney, L. W., de Kock, H. L., \& Taylor, J. R. (2008). Effects of sorghum type and milling process on the sensory characteristics of sorghum porridge. Cereal Chemistry, 85(3), 307-313. doi: 10.1094/CCHEM-853-0307

Khumalo, T. P., Schönfeldt, H. C., \& Vermeulen, H. (2011). Consumer acceptability and perceptions of maize meal in Giyani, South Africa. Development Southern Africa, 28(2), 271-281. doi: 10.1080/0376835X.2011.570074

Kihlberg, I. (2004). Sensory quality and consumer preception of wheat bread: Towards sustainable production and consumption (Doctoral dissertation). Retrieved from Uppsala University Dissertations. (URN: urn:nbn:se:uu:diva-4529). http://uu.diva-portal.org/smash/record.jsf?pid=diva2:165045 Accessed on 3rd March 2015. 
Kihlberg, I., Johansson, L., Langsrud, Ø., \& Risvik, E. (2005). Effects of information on liking of bread. Food Quality and Preference, 16(1), 25-35. doi: 10.1016/j.foodqual.2003.12.005

Kirchhoff, E., \& Schieberle, P. (2002). Quantitation of odor-active compounds in rye flour and rye sourdough using stable isotope dilution assays. Journal of Agricultural and Food Chemistry, 50(19), 5378-5385. doi: $10.1021 / \mathrm{jf} 020236 \mathrm{~h}$

Van Kleef, E., Vrijhof, M., Polet, I. A., Vingerhoeds, M. H. \& de Wijk, R. A. (2014). Nudging children towards whole wheat bread: a field experiment on the influence of fun bread roll shape on breakfast consumption. BMC Public Health 14(1), 906. doi:10.1186/1471-2458-14-906

Klensporf, D., \& Jeleń, H. H. (2008). Effect of heat treatment on the flavor of oat flakes. Journal of cereal science, 48(3), 656-661. doi: 10.1016/j.j.j.2008.02.005

Kobue-Lekalake, R. I., Taylor, J., \& De Kock, H. L. (2007). Effects of phenolics in sorghum grain on its bitterness, astringency and other sensory properties. Journal of the Science of Food and Agriculture, 87(10), 1940-1948. doi: $10.1002 /$ jsfa.2940

Kobue-Lekalake, R. I., Taylor, J., \& De Kock, H. L. (2009). Influence of PROP taster status on the consumer acceptability of food made from tannin sorghums. Journal of the Science of Food and Agriculture, 89(11), 1809-1814. doi: 10.1002/jsfa.3634

Kebakile, M. M., Rooney, L. W., de Kock, H. L., \& Taylor, J. R. (2008). Effects of sorghum type and milling process on the sensory characteristics of sorghum porridge. Cereal Chemistry, 85(3), 307-313. doi: 10.1094/CCHEM-853-0307

Kobue-Lekalake, R. I. (2008). Sensory perception of bitterness and astringency in sorghum (Doctoral dissertation). Retrieved from University of Pretoria Dissertations and theses [9088]. (http://hdl.handle.net/2263/23317)

Kordonowy, R. K., \& Youngs, V. L. (1985). Utilization of durum bran and its effect on spaghetti. Cereal Chemistry, 62(4), 301-308.

Ktenioudaki, A., \& Gallagher, E. (2012). Recent advances in the development of high-fibre baked products. Trends in Food Science \& Technology, 28(1), 4-14. doi: 10.1016/j.tifs.2012.06.004

Kuznesof, S., Brownlee, I. A., Moore, C., Richardson, D. P., Jebb, S. A., \& Seal, C. J. (2012). Wholeheart study participant acceptance of wholegrain foods. Appetite, 59(1), 187-193. doi: 10.1016/j.appet.2012.04.014

Lai, C., Hoseney, R., \& Davis, A. (1989). Effects of wheat bran in breadmaking. Cereal Chemistry, 66(3), 217-219.

Lang, R., \& Jebb, S. A. (2003). Who consumes whole grains, and how much. Proceedings of the Nutrition Society, 62(1), 123-127. Doi: 10.1079/PNS2002219

Lapveteläinen, A., \& Rannikko, H. (2000). Quantitative sensory profiling of cooked oatmeal. LWT-Food Science and Technology, 33(5), 374-379. doi:10.1006/fstl.2000.0675

Lee, K. D., \& Warthesen, J. J. (1996b). Mobile phases in reverse-phase HPLC for the determination of bitter peptides in cheese. Journal of Food Science, 61(2), 291-294. doi: 10.1111/j.1365-2621.1996.tb14178.x

Lee, K. D., \& Warthesen, J. J. (1996a). Preparative methods of isolating bitter peptides from Cheddar cheese. Journal of Agricultural and Food Chemistry, 44(4), 1058-1063. doi: 10.1021/jf950521j

Leland, J. V. (1997). Flavour interactions: the greater whole. Food technology, 51(1):78-80 
Lemieux, L., \& Simard, R. (1992). Bitter flavour in dairy products. II. A review of bitter peptides from caseins: their formation, isolation and identification, structure masking and inhibition. Le Lait, 72(4), 335-385. doi: 10.1051/lait:1992426

Liu, Y., Hsieh, F., Heymann, H., \& Huff, H. (2000). Effect of process conditions on the physical and sensory properties of extruded oat-corn puff. Journal of Food Science, 65(7), 1253-1259. doi: 10.1111/j.13652621.2000.tb10274.x

Liukkonen, K-H., Katina, K., Wilhelmsson, A., Myllymäki, O., Lampi, A. M., Kariluoto, S., et al. (2003). Processinduced changes on bioactive compounds in whole grain rye. Proceedings of the Nutrition Society of London, 62, 117-122. doi: 10.1079/PNS2002218

Lorenz, K., \& Brummer, J.-M. (2003). Preferments and sourdoughs for German breads. In Kulp, K., \& Lorenz, K. (Eds.). Handbook of dough fermentations, (pp. 247-270). New York: Marcel Dekker.

Lobato, L., Anibal, D., Lazaretti, M. \& Grossmann, M. (2011). Extruded puffed functional ingredient with oat bran and soy flour. LWT-Food Science and Technology, 44(4), 933-939.

Lotong, V., Edgar-Chambers, I., \& Chambers, D. H. (2000). Determination of the sensory attributes of wheat sourdough bread 1. Journal of Sensory Studies, 15(3), 309-326. doi: 10.1111/j.1745-459X.2000.tb00273.x

Mäkinen, O. E., \& Arendt, E. K. (2012). Oat malt as a baking ingredient-A comparative study of the impact of oat, barley and wheat malts on bread and dough properties. Journal of Cereal Science, 56(3), 747-753. doi: 10.1016/j.jcs.2012.08.009

Mariani-Costantini, A. (1988). Image and nutritional role of pasta in changing food patterns. In G. Fabriani \& C. Lintas (Eds.), Durum Wheat: Chemistry and Technology (283-302). St. Paul, MN: AACC Inc.

Martínez-Anaya, M. A. (1996). Enzymes and bread flavor. Journal of Agricultural and Food Chemistry, 44(9), 2469-2480. doi: 10.1021/jf960020d

Martins, Y., \& Pliner, P. (1998). The development of the food motivation scale. Appetite, 30(1), 94. doi: 10.1006/appe.1997.0127

Mattila, P., Pihlava, J., \& Hellström, J. (2005). Contents of phenolic acids, alkyl-and alkenylresorcinols, and avenanthramides in commercial grain products. Journal of Agricultural and Food Chemistry, 53(21), 8290-8295. doi: $10.1021 / \mathrm{jf} 051437 \mathrm{z}$

Mkandawire, N.L., Weier, S.A., Weller, C.L., Jackson, D.S. \& Rose, D.J. (2015). Composition, in vitro digestibility, and sensory evaluation of extruded whole grain sorghum breakfast cereals. Food Science and Technology, 62, 662-667.

Moder, G., Finney, K., Bruinsma, B., Ponte, J., \& Bolte, L. (1984). Bread-making potential of straight-grade and whole-wheat flours of Triumph and Eagle-Plainsman V hard red winter wheats. Cereal Chemistry, 61(4), 269-273.

Molteberg, E., Solheim, R., Dimberg, L., \& Frølich, W. (1996). Variation in oat groats due to variety, storage and heat treatment. II: Sensory quality. Journal of cereal science, 24(3), 273-282. doi: 10.1006/jcrs.1996.0059

Mouquet-Rivier, C., Icard-Vernière, C., Guyot, J., Hassane Tou, E., Rochette, I., \& Treche, S. (2008). Consumption pattern, biochemical composition and nutritional value of fermented pearl millet gruels in Burkina Faso. International Journal of Food Sciences and Nutrition, 59(7-8), 716-729. doi: $10.1080 / 09637480802206389$ 
Nantanga, K. K. M, Seetharaman, K., de Kock, H. L., \& Taylor, J. (2008). Thermal treatments to partially pre-cook and improve the shelf-life of whole pearl millet flour. Journal of the Science of Food and Agriculture, 88(11), 1892-1899. doi: 10.1002/jsfa.3291

Noort, M. W. J., van Haaster, D., Hemery, Y., Schols, H. A., \& Hamer, R. J. (2010). The effect of particle size of wheat bran fractions on bread quality- Evidence for fibre-protein interactions. Journal of cereal science, 52(1), 59-64. doi: $10.1016 / j . j c s .2010 .03 .003$

Nordlund, E., Heiniö, R-L., Viljanen, K., Pihlava, J., Lehtinen, P., \& Poutanen, K. (2013). Flavour and stability of rye grain fractions in relation to their chemical composition. Food Research International, 54(1), 48-56. doi: 10.1016/j.foodres.2013.05.034

Omoba, O.S., Taylor, J.R.N. \& de Kock, H.L. (2015). Sensory and nutritive profiles of biscuits from whole grain sorghum and pearl millet plus soya flour with and without sourdough fermentation. International Journal of Food Science and Technology, 1-8. doi:10.1111/ijfs.12923

Parada, J., Aguilera, J. M., \& Brennan, C. (2011). Effect of guar gum content on some physical and nutritional properties of extruded products. Journal of Food Engineering, 103(3), 324-332.

Pareyt, B., \& Delcour, J. A. (2008). The role of wheat flour constituents, sugar, and fat in low moisture cereal based products: a review on sugar-snap cookies. Critical Reviews in Food Science and Nutrition, 48(9), 824-839. doi: $10.1080 / 10408390701719223$

Parker, J. K., Hassell, G. M. E., Mottram, D. S., \& Guy, R. C. E. (2000). Sensory and instrumental analyses of volatiles generated during the extrusion cooking of oat flours. Journal of Agricultural and Food Chemistry, 48, 3497-3506. doi: 10.1021/jf991302r

Pomeranz, Y., Shogren, M., Finney, K., \& Bechtel, D. (1977). Fiber in breadmaking-effects on functional properties. Cereal Chemistry, 54, 25-41.

Poutanen, K., Flander, L., \& Katina, K. (2009). Sourdough and cereal fermentation in a nutritional perspective. Food Microbiology, 26(7), 693-699. doi:10.1016/j.fm.2009.07.011

Poutanen, K., Sozer, N., \& Della Valle, G. (2014). How can technology help to deliver more of grain in cereal foods for a healthy diet? Journal of Cereal Science, 59(3), 327-336. doi: 10.1016/j.jcs.2014.01.009

Rizzello, C. G., Coda, R., Mazzacane, F., Minervini, D., \& Gobbetti, M. (2012). Micronized by-products from debranned durum wheat and sourdough fermentation enhanced the nutritional, textural and sensory features of bread. Food Research International, 46(1), 304-313. doi: 10.1016/j.foodres.2011.12.024

Robin, F., Dubois, C., Pineau, N., Schuchmann, H. P., \& Palzer, S. (2011). Expansion mechanism of extruded foams supplemented with wheat bran. Journal of Food Engineering, 107(1), 80-89. doi: 10.1016/j.jfoodeng.2011.05.041

Roland, W. S. U. (2014). Intrinsic bitterness of flavonoids and isoflavonoids and masking their taste activity. (Doctoral dissertation). Retrieved from Wageningen UR Library. Wageningen University dissertation [5723]. (http://edepot.wur.nl/300398)

Roininen, K., \& Tuorila, H. (1999). Health and taste attitudes in the prediction of use frequency and choice between less healthy and more healthy snacks. Food Quality and Preference, 10(4), 357-365. doi: 10.1016/S09503293(98)00057-3

Rouzaud, O., \& Martínez-Anaya, M. A. (1997). Relationships between biochemical and quality-related characteristics of breads, resulting from the interaction of flour, microbial starter and the type of process. Zeitschrift Für Lebensmitteluntersuchung Und-Forschung A, 204(4), 321-326. 
Saba, A., Vassallo, M., Shepherd, R., Lampila, P., Arvola, A., Dean, M., et al. (2010). Country-wise differences in perception of health-related messages in cereal-based food products. Food Quality and Preference, 21(4), 385-393. doi: 10.1016/j.foodqual.2009.09.007

Sahlström, S., Mosleth, E., Bævre, A. B., Gloria, H. \& Fayard, G. (1993). Influence of starch, gluten proteins and extraction rate on bread and pasta quality.Carbohydrate Polymers 21(2), 169-175.

Salmenkallio-Marttila, M., Roininen, K., Lindgren, J., Rousu, J., Autio, K., \& Lähteenmäki, L. (2004). Applying machine learning methods in studying relationships between mouthfeel and microstructure of oat bread. Journal of Texture Studies, 35(3), 225-250. doi: 10.1111/j.1745-4603.2004.tb00835.x

Sandvik, P., Kihlberg, I., Lindroos, A. K., Marklinder, I., \& Nydahl, M. (2014). Bread consumption patterns in a Swedish national dietary survey focusing particularly on whole-grain and rye bread. Food and Nutrition Research, 58, 24024. doi: 10.3402/fnr.v58.24024

Schaffer-Lequart, C., Lehmann, U., Ross, A. B., Roger, O., Eldridge, A. L., Ananta, E., Bietry, M., King, L. R., Moroni, A., \& Srichuwong, S. (2015). Whole Grain in Manufactured Foods: Current use, Challenges and the way Forward. Critical Reviews in Food Science and Nutrition (just-accepted), 00-00. doi: $10.1080 / 10408398.2013 .781012$

Seal, C., Jones, A., \& Whitney, A. (2006). Wholegrains uncovered. Nutrition Bulletin, 31(2), 129-137. doi: 10.1111/j.1467-3010.2006.00559.x

Shepherd, R., Dean, M., Lampila, P., Arvola, A., Saba, A., Vassallo, M., et al. (2012). Communicating the benefits of wholegrain and functional grain products to European consumers. Trends in Food Science \& Technology, 25(2), 63-69. doi: 10.1016/j.tifs.2012.01.002

Shogren, M., Pomeranz, Y., \& Finney, K. (1981). Counteracting the deleterious effects of fiber in breadmaking. Cereal Chemistry, 58, 142-144.

Sibakov, J. K., Kirjoranta, S. J., Alam, S. A., Kokkonen, H., Jurvelin, J. S., Jouppila, K., Poutanen, K. S., \& Sozer, N. (2015). Effect of oat bran fractions on extrudates made of defatted oats. Food and Bioprocess Technology, 8(2), 445-458. doi: 10.1007/s11947-014-1425-4

Slavin, J. L. (2000). Mechanisms for the impact of whole grain foods on cancer risk. Journal of the American College of Nutrition, 19(sup3), 300S-307S. doi: 10.1080/07315724.2000.10718964

Soares, S., Kohl, S., Thalmann, S., Mateus, N., Meyerhof, W. \& De Freitas, V. (2013). Different phenolic compounds activate distinct human bitter taste receptors. Journal of Agricultural and Food Chemistry, 61(7), 1525-1533. doi: $10.1021 / \mathrm{jf} 304198 \mathrm{k}$

Sobota, A., Rzedzicki, Z., Zarzycki, P. \& Kuzawińska, E. (2015). Application of common wheat bran for the industrial production of high-fibre pasta.International Journal of Food Science \& Technology 50(1), 111-119.

Soong, Y. Y., Quek, R. Y. C., \& Henry, C. J. (2015). Glycemic potency of muffins made with wheat, rice, corn, oat and barley flours: a comparative study between in vivo and in vitro. European Journal of Nutrition, 1-5. doi: 10.1007/s00394-014-0806-9.

Sozer, N., \& Poutanen, K. (2013). Fibre in extruded food products. In J. A. Delcour \& K. Poutanen (Eds.). Fibre-rich and wholegrain foods-improving quality, (pp. 256-268). Cambridge: Woodhead Publishing Ltd.

Sozer, N., Dalgıc, A., \& Kaya, A. (2007). Thermal, textural and cooking properties of spaghetti enriched with resistant starch. Journal of Food Engineering, 81(2), 476-484. doi:10.1016/j.jfoodeng.2006.11.026 
Sozer, N., Kaya, A. \& Dalgic, A. C. (2008). The effect of resistant starch addition on viscoelastic properties of cooked spaghetti. Journal of Texture Studies, 39(1), 1-16. doi: 10.1111/j.1745-4603.2007.00126.x

Sozer, N., Cicerelli, L., Heiniö, R., \& Poutanen, K. (2014). Effect of wheat bran addition on in vitro starch digestibility, physico-mechanical and sensory properties of biscuits. Journal of Cereal Science, 60(1), 105-113. doi: $10.1016 /$ j.jcs.2014.01.022

Sozer, N., Juvonen, R., Katina, K., \& Poutanen, K. (2014). Patent application FI 20145873. Method for modifying brans, and products comprising modified bran. EU Patent and Trademark Office.

Spicher, G., \& Nierle, W. (1988). Proteolytic activity of sourdough bacteria. Applied Microbiology and Biotechnology, 28(4-5), 487-492.

Stanyon, P., \& Costello, C. (1990). Effects of wheat bran and polydextrose on the sensory characteristics of biscuits. Cereal Chemistry, 67(6), 545-547.

Starr, G., Bredie, W. L. P., \& Hansen, Å. S. (2013). Sensory profiles of cooked grains from wheat species and varieties. Journal of Cereal Science, 57, 295-303. doi: 10.1016/j.jcs.2012.11.014

Steptoe, A., Pollard, T. M., \& Wardle, J. (1995). Development of a measure of the motives underlying the selection of food: the food choice questionnaire. Appetite, 25(3), 267-284. doi: 10.1006/appe.1995.0061

Sudha, M., Vetrimani, R., \& Leelavathi, K. (2007). Influence of fibre from different cereals on the rheological characteristics of wheat flour dough and on biscuit quality. Food Chemistry, 100(4), 1365-1370. doi: 10.1016/j.foodchem.2005.12.013

Taylor, A., \& Linforth, R. (1996). Flavour release in the mouth. Trends in Food Science \& Technology, 7(12), 444-448. doi: 10.1016/S0924-2244(96)10046-7

Thane, C., Jones, A., Stephen, A., Seal, C., \& Jebb, S. (2005). Whole-grain intake of British young people aged 4-18 years. British Journal of Nutrition, 94(5), 825-831. doi: 10.1079/BJN20051557

Thiele, C., Gänzle, M., \& Vogel, R. (2002). Contribution of sourdough lactobacilli, yeast, and cereal enzymes to the generation of amino acids in dough relevant for bread flavor. Cereal Chemistry, 79(1), 45-51. Doi: 10.1094/CCHEM.2002.79.1.45

Tuorila, H., \& Cardello, A. V. (2002). Consumer responses to an off-flavour in juice in the presence of specific health claims. Food Quality and Preference, 13(7), 561-569. doi: 10.1016/S0950-3293(01)00076-3

Van Gemert, L. J. (2011). Odour thresholds. Compilations of odour threshold values in air, water and other media (pp 11-80). Utrecht: Oliemans Punter \& Partners BV.

Verbeke, W. (2005). Consumer acceptance of functional foods: socio-demographic, cognitive and attitudinal determinants. Food quality and preference, 16(1), 45-57. doi: 10.1016/j.foodqual.2004.01.001

Wang, M., Hamer, R., Van Vliet, T., Gruppen, H., Marseille, H., \& Weegels, P. (2003a). Effect of water unextractable solids on gluten formation and properties: mechanistic considerations. Journal of Cereal Science, 37(1), 55-64. doi: $10.1006 /$ jcrs. 2002.0478

Wang, M., Oudgenoeg, G., van Vliet, T., \& Hamer, R. J. (2003b). Interaction of water unextractable solids with gluten protein: effect on dough properties and gluten quality. Journal of Cereal Science, 38(1), 95-104. doi: 10.1016/S0733-5210(03)00018-3 
Wang, M., van Vliet, T., \& Hamer, R. J. (2004a). Evidence that pentosans and xylanase affect the re-agglomeration of the gluten network. Journal of Cereal Science, 39(3), 341-349. doi: 10.1016/j.jcs.2003.12.003

Wang, M., van Vliet, T., \& Hamer, R. J. (2004b). How gluten properties are affected by pentosans. Journal of Cereal Science, 39(3), 395-402. doi:10.1016/j.jcs.2004.02.002

West, R., Duizer, L. \& Seetharaman, K. (2013a). The effect of drying and whole grain content on the pasting, physicochemical and qualitative properties of pasta. Starch-stärke, 65(7-8), 645-652. doi: 10.1002/star.201200212

West, R., Seetharaman, K. \& Duizer, L. M. (2013b). Whole grain macaroni: Flavour interactions with sodium-reduced cheese sauce. Food Research International, 53(1), 149-155. doi: 10.1016/j.foodres.2013.04.002

West, R., Seetharaman, K., \& Duizer, L.M. (2013c). Effect of drying profile and whole grain content on flavour and texture of pasta. Journal of Cereal Science, 58, 82-88. doi: 10.1016/j.jcs.2013.03.018

Yao, N., Jannink, J., Alavi, S., \& White, P. J. (2006). Physical and sensory characteristics of extruded products made from two oat lines with different $\beta$-glucan concentrations. Cereal Chemistry, 83(6), 692-699. doi: 10.1094/CC83-0692

Yao, N., White, P. J., \& Alavi, S. (2011). Impact of $\beta$-glucan and other oat flour components on physic-chemical and sensory properties of extruded oat cereals. International Journal of Food Science and Technology, 46(3), 651-660. doi: 10.1111/j.1365-2621.2010.02535.x

Ye, E. Q., Chacko, S. A., Chou, E. L., Kugizaki, M., \& Liu, S. (2012). Greater whole-grain intake is associated with lower risk of type 2 diabetes, cardiovascular disease, and weight gain. The Journal of Nutrition, 142(7), 1304-1313. doi: 10.3945/jn.111.155325

Zehentbauer, G. \& Grosch, W. (1998). Crust aroma of baguettes I. Key odorants of baguettes prepared in two different ways. Journal of Cereal Science 28(1), 81-92. doi: 10.1006/jcrs.1998.0184

Zehentbauer, G., \& Grosch, W. (1998). Crust aroma of baguettes II. Dependence of the concentrations of key odorants on yeast level and dough processing. Journal of Cereal Science, 28(1), 93-96. doi:_10.1006/jcrs.1998.0183

Zeppa, G., Bertolino, M., \& Rolle, L. (2012). Quantitative descriptive analysis of Italian polenta produced with different corn cultivars. Journal of the Science of Food and Agriculture. 92(2), 412-417. doi: 10.1002/jsfa.4593

Zhang, D., \& Moore, W. R. (1999). Wheat bran particle size effects on bread baking performance and quality. Journal of the Science of Food and Agriculture, 79(6), 805-809. Doi: 10.1002/(SICI)10970010(19990501)79:6<805::AID-JSFA285>3.0.CO;2-E

Zhou, M., Robards, K., Glennie-Holmes, M. \& Helliwell, S. (2000). Contribution of volatiles to the flavour of oatmeal. Journal of the Science of Food and Agriculture, 80(2), 247-254. doi: 10.1002/(SICI)10970010(20000115)80:2<247::AID-JSFA525>3.0.CO;2-0 